\title{
Archaeological Investigations at the Walnut Branch (41CE47), Ross I (41CE485), and Ross II (41CE486) Sites, Cherokee County, Texas
}

Timothy K. Perttula

Heritage Research Center, Stephen F. Austin State University

Kevin Stingley

Texas Archeological Stewardship Network, Texas Historical Commission

Follow this and additional works at: https://scholarworks.sfasu.edu/ita

Part of the American Material Culture Commons, Archaeological Anthropology Commons, Environmental Studies Commons, Other American Studies Commons, Other Arts and Humanities Commons, Other History of Art, Architecture, and Archaeology Commons, and the United States History Commons

Tell us how this article helped you.

This Article is brought to you for free and open access by the Center for Regional Heritage Research at SFA ScholarWorks. It has been accepted for inclusion in Index of Texas Archaeology: Open Access Gray Literature from the Lone Star State by an authorized editor of SFA ScholarWorks. For more information, please contact cdsscholarworks@sfasu.edu. 
Archaeological Investigations at the Walnut Branch (41CE47), Ross I (41CE485), and Ross II (41CE486) Sites, Cherokee County, Texas

\section{Creative Commons License}

\section{(c) (i) (8)}

This work is licensed under a Creative Commons Attribution-NonCommercial 4.0 International License 


\section{Archaeological Investigations at the Walnut Branch (41CE47), Ross I (41CE485), and Ross II (41CE486) Sites, Cherokee County, Texas}

Timothy K. Perttula and Kevin Stingley

\section{Introduction}

The Walnut Branch site (41CE47) was recorded by George Kegley and Dan Witter in 1969 as part of an archaeological survey funded by the Texas Building Commission (now the Texas Historical Commission) in Cherokee County and adjacent counties. This ancestral Caddo site is located about six miles southwest of the city of Rusk, in the Box's Creek valley in the Neches River basin; Box's Creek is a generally southern-flowing tributary to the Neches River, and enters the river not far to the westnorthwest of the George C. Davis site (41CE19), otherwise known as Caddo Mounds State Historic Site. The landowner's son had previously collected ceramic sherds and a ceramic pipe from the Walnut Branch site, and a Caddo burial (and associated ceramic vessel, about which nothing is known) had been found at the site in 1964.

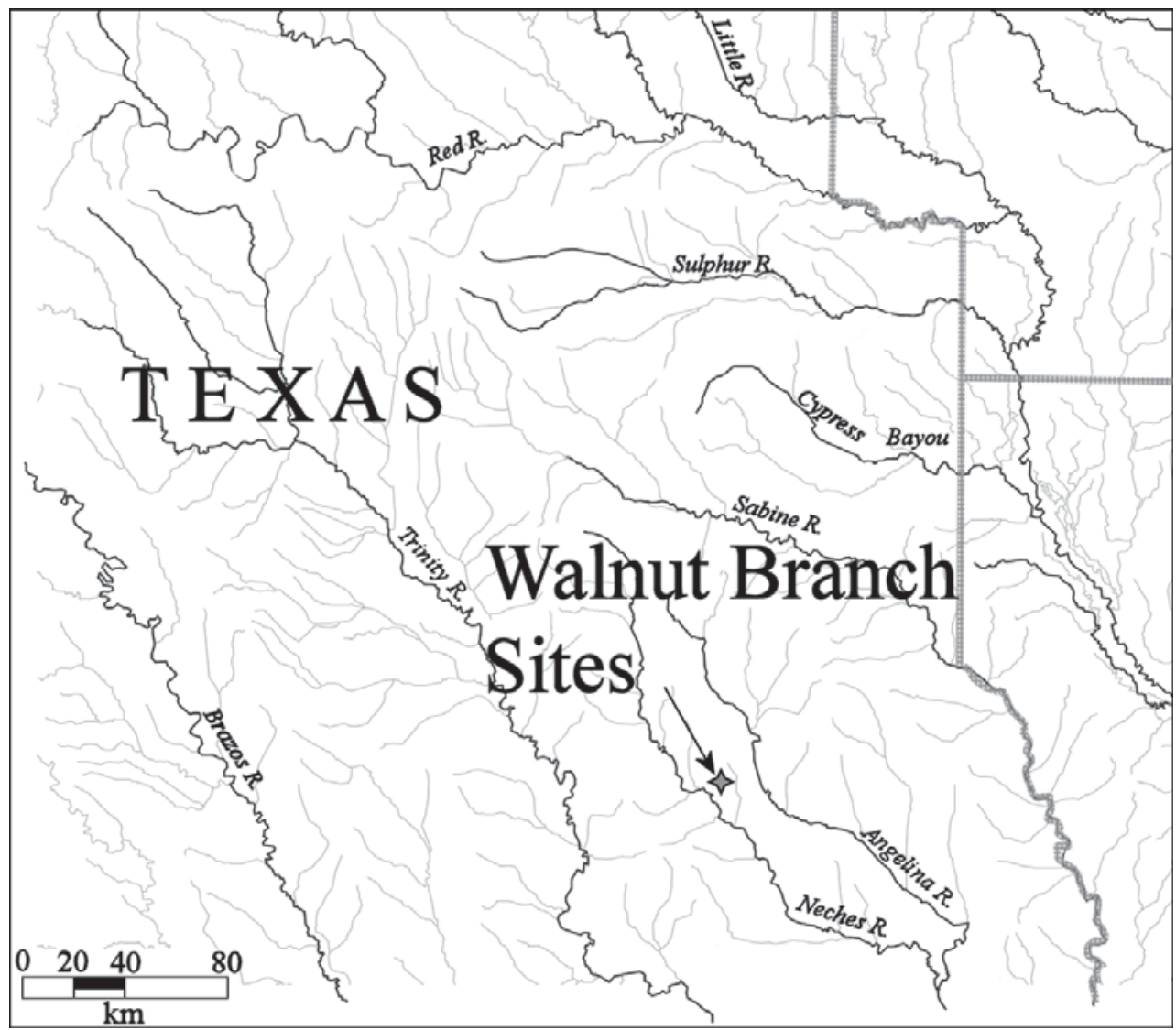

Figure 1. The general location of the Walnut Branch site (41CE47) and nearby Ross I (41CE485) and Ross II (41CE486) sites in East Texas. 
Kegley obtained surface collections of ceramic sherds and lithic tools from different parts of the Walnut Branch site, including a number of ceramic sherds $(n=69)$ and one tool fragment from the Walnut Branch stream bed, a tributary to Box's Creek; at that time, the bank of the stream was actively eroding, exposing artifacts on the surface. Kegley also excavated two small "test pits" or shovel tests at the site, and they contained a small number of ceramic sherds in the archaeological deposits. The sediments in those "test pits" had different zones of alluvial sands to a depth of at least $58 \mathrm{~cm}$.

In 2017, the junior author obtained permission to reexamine the Walnut Branch site, and determine its current condition and research significance. This work consisted of an intensive program of shovel testing across a large field and floodplain north of Walnut Branch and east of Box's Creek, which is discussed below. He also obtained a substantial collection of ancestral Caddo ceramic vessel sherds from the Walnut Branch stream bed just below the Walnut Branch site and the Ross I site; this surface collection was taken before the shovel testing work was initiated. The intensive shovel testing has demonstrated that the large pasture that contains the Walnut Branch site also contains two other spatially related ancestral Caddo sites (Ross I, 41CE485 and Ross II, 41CE486) to the west and northeast, respectively, of the Walnut Branch site (Figure 2); the findings from these other sites will also be discussed in this article.

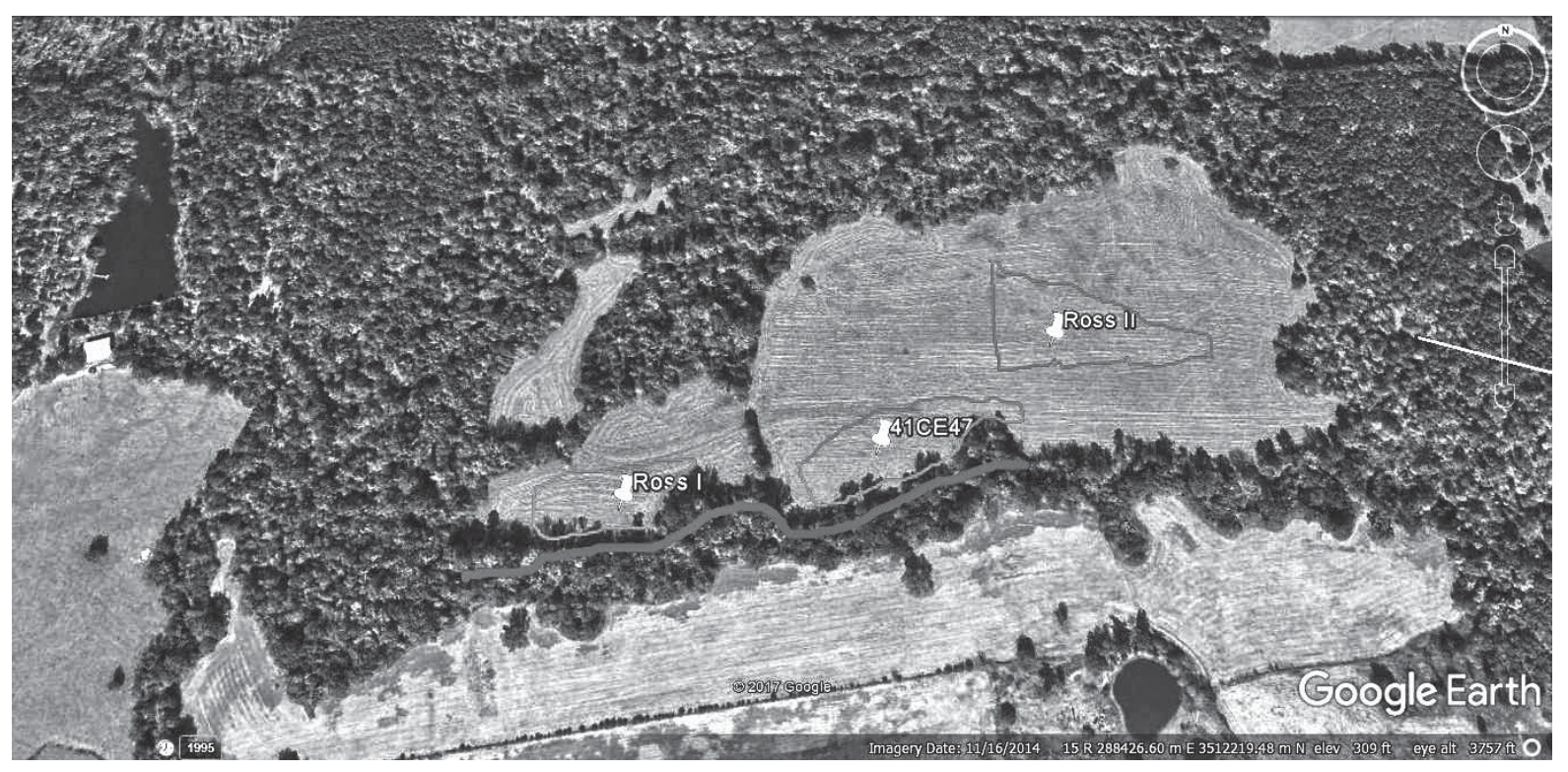

Figure 2. The setting of the Walnut Branch site and Ross I and II sites along Walnut Branch and Box's Creek. The surface collection area is marked in blue along Walnut Branch by the Walnut Branch and Ross I sites

\section{Box's Creek and Walnut Branch Setting}

The three ancestral Caddo sites discussed herein are situated in the pasture-covered floodplain of Walnut Branch and Box's Creek. Walnut Branch flows west to its confluence with Box's Creek, not far to the west of the third site (see Figure 2). The area along Walnut Branch is wooded, as is the Box's Creek valley in the vicinity of the sites. The floodplain soil is Hannahatchee fine sandy loam (Mowery 1959:22), with a 0-1 percent slope, and based on the shovel tests, it ranges in thickness from ca. $30 \mathrm{~cm}$ to more than $100 \mathrm{~cm}$ bs, and is underlain by a B-Horizon clay zone. 


\section{Kegley 1969 Collections from the Walnut Branch site (41CE47)}

Kegley's collections from the Walnut Branch site at the Texas Archeological Research Laboratory at The University of Texas at Austin were collected in 1969. They include four ceramic sherds from test pits 1 and 2 and 70 ceramic sherds from a stream bed surface collection. They are from plain, utility, and fine ware vessels (Table 1); the two rim sherds are from utility ware vessels. The plain to decorated sherd ratio in this assemblage is 1.18 , and utility ware sherds comprise approximately 91 percent of the decorated sherds in the Kegley assemblage.

Table 1. Ceramic sherd assemblage from the 1969 collections at the Walnut Branch site.

\begin{tabular}{lllll}
\hline Ware & Rim & Body & Base & N \\
\hline Plain & - & 36 & 4 & 40 \\
Utility & 2 & 29 & - & 31 \\
Fine & - & 3 & - & 3 \\
\hline Totals & 2 & 68 & 4 & 74 \\
\hline
\end{tabular}

The majority of the sherds are from vessels tempered with grog and crushed hematite (47 percent) and grog (34 percent) (Table 2). In total, more than 95 percent of the sherds have grog as a principal temper in vessel manufacture. Sherds from vessels tempered solely with burned bone comprise only 2.7 percent of the Kegley assemblage, but another 10.8 percent have burned bone aplastics in combination with hematite, grog, or grog and hematite. About 5.4 percent of the sherds are from vessels with a sandy paste.

Table 2. Temper and paste characteristics of the Kegley sherd assemblage from the Walnut Branch site.

\begin{tabular}{lllll}
\hline Temper and paste & Plain & Utility & Fine & N \\
\hline bone & - & 2 & - & 2 \\
bone-hematite & - & 1 & - & 1 \\
grog & 14 & 10 & 1 & 25 \\
grog-sandy paste & 2 & 1 & 1 & 4 \\
grog-bone & 1 & 1 & - & 2 \\
grog-bone-hematite & 4 & 1 & - & 5 \\
grog-hematite & 19 & 15 & 1 & 35 \\
\hline Totals & 40 & 31 & 3 & 74 \\
\hline
\end{tabular}

About 87 percent of the utility wares are from vessels with brushed or brushed-incised decorative elements (Table 3). These are likely from Bullard Brushed jars (Suhm and Jelks 1962:Plate 11); the thickness of some of the recovered sherds $(>10 \mathrm{~mm})$ suggests that in some cases large jars were 
manufactured and used at the Walnut Branch site. The few incised and pinched sherds are from Maydelle Incised and Killough Pinched vessels (see Suhm and Jelks 1962:Plates 46 and 52). The typological classification of the fingernail and tool punctated sherds in the Walnut Branch site collection is uncertain.

Table 3. Decorative methods and elements in the Kegley sherd collection from the Walnut Branch site.

\begin{tabular}{llll}
\hline Method and decorative element & Rim & Body & N
\end{tabular}

\section{Utility ware}

Brushed

opposed brushed marks $-3$

parallel brushed marks

$\begin{array}{lll}- & 16 & 16\end{array}$

\section{Brushed-incised}

horizontal brushed-incised marks and lines

parallel brushed-incised marks and lines

$\begin{array}{lll}1 & 1 & 2 \\ - & 6 & 6\end{array}$

Incised

parallel incised lines

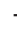

1

1

\section{Pinched}

straight pinched ridge

\section{Punctated}

fingernail punctated row under lip

tool punctated rows

$\begin{array}{lll}1 & - & 1\end{array}$

\section{Fine ware}

\section{Engraved}

curvilinear engraved lines

\section{Trailed}

opposed curvilinear trailed lines

Totals

Fine ware sherds are not common in the Kegley sherd assemblage from the Walnut Branch site, accounting for only 8.8 percent of the assemblage (see Table 3 ). Two of the engraved sherds have curvilinear engraved lines, and they may be from Poynor Engraved vessels (see Suhm and Jelks 1962:Plate 62). The trailed sherd with opposed curvilinear trailed lines is from a Keno Trailed bowl (see Suhm and Jelks 1962:Plate 44f). The Keno Trailed vessel sherd suggests that the Walnut Branch site was used to some extent after ca. A.D. 1680, but the other sherds perhaps point to a principal use of the site sometime during the Late Caddo period Frankston phase (ca. A.D. 1400-1680). We will return to the question of the estimated age of the Walnut Branch site, as well as the Ross I and Ross II sites, after discussing the character of the artifacts recovered from these sites in the 2017 archaeological investigations. 


\section{Surface Collection of the Walnut Branch stream bed from the Walnut Branch site and the Ross I site}

The surface collection of the Walnut Branch stream bed was done in February 2017, before the shovel testing work in the field north of the branch was done. The stream bed was walked twice by the Walnut Branch site to the Ross I site to reconnoiter for surface artifacts eroded from the cut bank (see Figure 2); at that time, it wasa thought that this was one site area, not two, so the surface collection artifacts were not separated by location along the stream bed. Visibility along the cut bank itself was poor because of vegetation growing along it, and no artifacts were noted in the cut bank.

The 2017 surface collection recovered 136 Caddo ceramic vessel sherds, 55 plain and 81 with decorative elements (see below), and a few lithic artifacts. These include two pieces of petrified wood lithic debris and part of the polished bit from a greenish-gray siliceous shale celt.

\section{Walnut Branch Site (41CE47)}

Intensive shovel testing was completed at the Walnut Branch site. This established that the site is approximately $110 \times 100 \mathrm{~m}$ in size, or ca. 2.7 acres (Figure 3). A total of 72 shovel tests on the landform have cultural materials (Table 4) which is 26.7 shovel tests per acre of the site. Sediments on the site are a fine sandy loam of variable thickness and color, and the clay B-horizon was not reached in any of the shovel tests. The majority of the artifacts are from 0-40 cm bs.

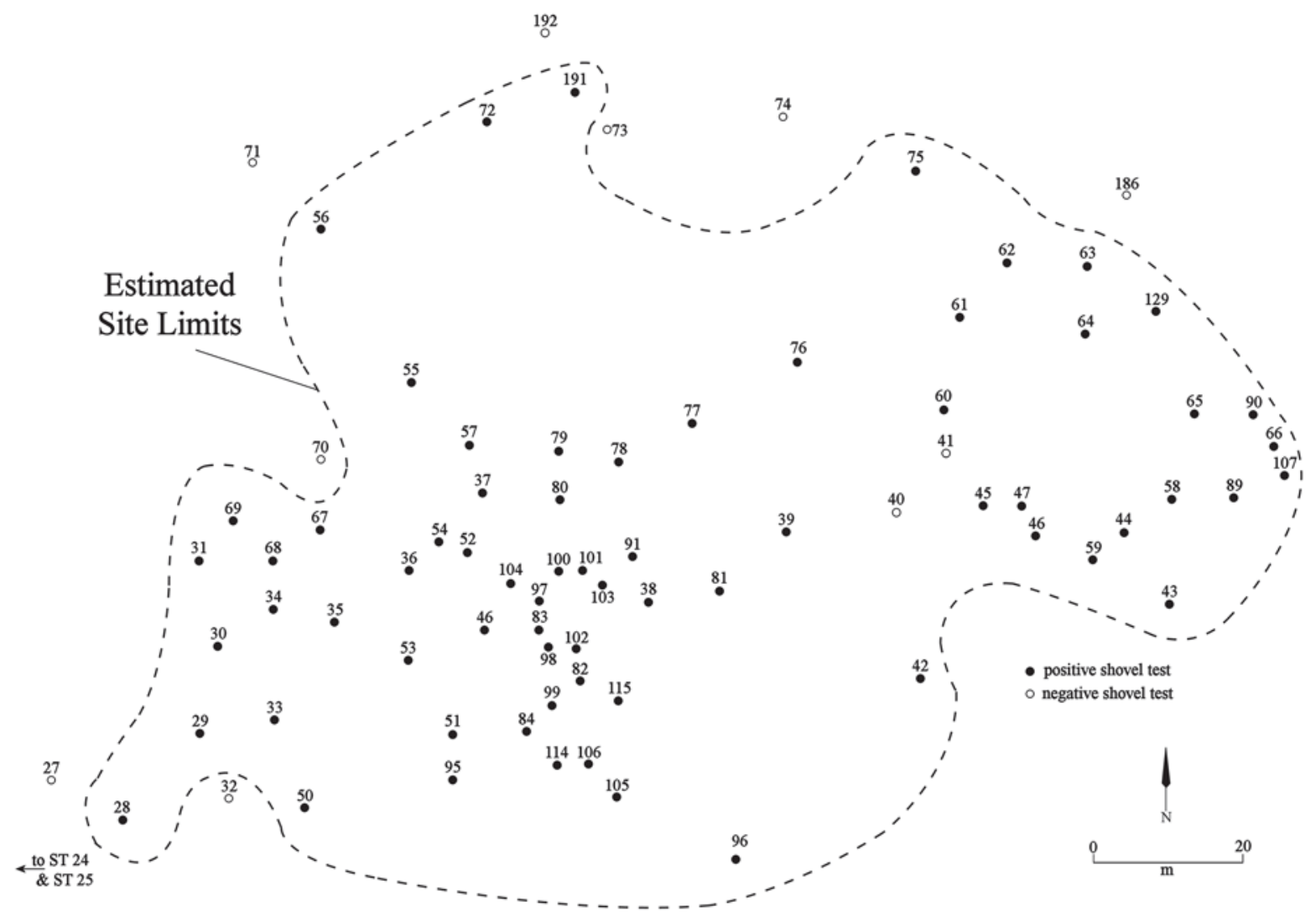

Figure 3. Map of the Walnut Branch site (41CE47). 
Table 4. Sediment descriptions in positive shovel tests at the Walnut Branch site.

\begin{tabular}{|c|c|}
\hline No. & Sediment description \\
\hline 24 & $0-56 \mathrm{~cm}+$, strong brown fine sandy loam \\
\hline 25 & $0-58 \mathrm{~cm}+$, strong brown fine sandy loam \\
\hline 28 & $0-39 \mathrm{~cm}+$, strong brown fine sandy loam \\
\hline 29 & $0-48 \mathrm{~cm}+$, strong brown fine sandy loam \\
\hline 30 & $0-42 \mathrm{~cm}+$, strong brown fine sandy loam \\
\hline 31 & $0-32 \mathrm{~cm}+$, strong brown fine sandy loam \\
\hline 33 & $0-47 \mathrm{~cm}+$, strong brown fine sandy loam \\
\hline 34 & $0-38 \mathrm{~cm}+$, strong brown fine sandy loam \\
\hline 35 & $0-47 \mathrm{~cm}+$, strong brown fine sandy loam \\
\hline 36 & $0-10 \mathrm{~cm}$, dark gray fine sandy loam; $10-52 \mathrm{~cm}+$, strong brown fine sandy loam \\
\hline 37 & $0-54 \mathrm{~cm}+$, strong brown fine sandy loam \\
\hline 38 & $0-10 \mathrm{~cm}$, very dark gray fine sandy loam; $10-51 \mathrm{~cm}+$, strong brown fine sandy loam \\
\hline 39 & 0-10 cm, very dark gray fine sandy loam; $10-60 \mathrm{~cm}+$, strong brown fine sandy loam \\
\hline 40 & $0-73 \mathrm{~cm}+$, strong brown fine sandy loam \\
\hline 42 & $0-10 \mathrm{~cm}$, black fine sandy loam; $10-40 \mathrm{~cm}+$, dark gray fine sandy loam \\
\hline 43 & $0-60 \mathrm{~cm}+$, reddish-yellow fine sandy loam \\
\hline 44 & $0-100 \mathrm{~cm}+$, reddish-yellow fine sandy loam \\
\hline 45 & $0-80 \mathrm{~cm}+$, reddish-yellow fine sandy loam \\
\hline 46 & $0-54 \mathrm{~cm}+$, reddish-yellow fine sandy loam \\
\hline 47 & $0-65 \mathrm{~cm}+$, reddish-yellow fine sandy loam \\
\hline 50 & $0-10 \mathrm{~cm}$, very dark gray fine sandy loam; $10-40 \mathrm{~cm}+$, strong brown fine sandy loam \\
\hline 51 & 0-45 cm, dark brown fine sandy loam; $45-68 \mathrm{~cm}+$, strong brown fine sandy loam \\
\hline 52 & 0-20 cm, dark brown fine sandy loam; $20-38 \mathrm{~cm}+$, strong brown fine sandy loam \\
\hline 53 & 0-20 cm, brown fine sandy loam; 20-39 cm+, black fine sandy loam \\
\hline 55 & $0-26 \mathrm{~cm}+$, brown fine sandy loam \\
\hline 56 & 0-10 cm, dark brown fine sandy loam; $10-28 \mathrm{~cm}+$, strong brown fine sandy loam \\
\hline 57 & 0-66 cm, strong brown fine sandy loam; $66 \mathrm{~cm}+$, strong brown clay with gray mottles \\
\hline 58 & $0-50 \mathrm{~cm}+$, strong brown fine sandy loam \\
\hline 59 & $0-100 \mathrm{~cm}+$, reddish-yellow fine sandy loam \\
\hline 60 & $0-63 \mathrm{~cm}$, strong brown fine sandy loam; $63 \mathrm{~cm}+$, reddish-yellow clay \\
\hline 61 & $0-44 \mathrm{~cm}+$, dark brown fine sandy loam \\
\hline 62 & $0-42 \mathrm{~cm}+$, dark brown fine sandy loam \\
\hline 63 & $0-54 \mathrm{~cm}+$, dark brown fine sandy loam \\
\hline 64 & $0-46 \mathrm{~cm}+$, brown fine sandy loam \\
\hline 65 & 0-60 cm+, strong brown fine sandy loam \\
\hline 66 & $0-38 \mathrm{~cm}+$, strong brown fine sandy loam \\
\hline 67 & $0-30 \mathrm{~cm}+$, dark brown fine sandy loam \\
\hline 68 & $0-42 \mathrm{~cm}+$, dark brown fine sandy loam \\
\hline 69 & 0-32 cm+, dark brown fine sandy loam \\
\hline 72 & 0-10 cm, dark brown fine sandy loam; $10-35 \mathrm{~cm}+$, strong brown fine sandy loam \\
\hline 75 & 0-25 cm, strong brown fine sandy loam; $25-54 \mathrm{~cm}+$, very dark gray fine sandy loam \\
\hline 76 & $\begin{array}{l}0-15 \mathrm{~cm} \text {, dark brown fine sandy loam; } 15-25 \mathrm{~cm} \text {, strong brown fine sandy loam; } 25-67 \mathrm{~cm}+\text {, gray } \\
\text { fine sandy loam }\end{array}$ \\
\hline 77 & $\begin{array}{l}0-15 \mathrm{~cm} \text {, dark brown fine sandy loam; } 15-25 \mathrm{~cm} \text {, strong brown fine sandy loam; } 25-59 \mathrm{~cm}+\text {, gray } \\
\text { fine sandy loam }\end{array}$ \\
\hline 78 & $0-48 \mathrm{~cm}+$, strong brown fine sandy loam \\
\hline 79 & $0-57 \mathrm{~cm}+$, brown fine sandy loam \\
\hline 80 & 0-15 cm, very dark gray fine sandy loam; $15-38 \mathrm{~cm}+$, brown fine sandy loam \\
\hline 81 & $0-83 \mathrm{~cm}+$, strong brown fine sandy loam \\
\hline 82 & 0-10 cm, dark brown fine sandy loam; $10-100 \mathrm{~cm}+$, strong brown fine sandy loam \\
\hline
\end{tabular}


Table 4. Sediment descriptions in positive shovel tests at the Walnut Branch site, cont.

\begin{tabular}{|c|c|}
\hline No. & Sediment description \\
\hline 83 & $0-58 \mathrm{~cm}+$, dark brown fine sandy loam \\
\hline 84 & $0-53 \mathrm{~cm}+$, brown fine sandy loam \\
\hline 89 & 0-72 $\mathrm{cm}+$, strong brown fine sandy loam \\
\hline 90 & $0-56 \mathrm{~cm}+$, strong brown fine sandy loam \\
\hline 91 & 0-13 cm, dark brown fine sandy loam; $13-51 \mathrm{~cm}+$, strong brown fine sandy loam \\
\hline 95 & $\begin{array}{l}\text { 0-20 cm, brown fine sandy loam; } 20-60 \mathrm{~cm} \text {, dark brown fine sandy loam; } 60-75 \mathrm{~cm} \text {, black fine } \\
\text { sandy loam; } 75-86 \mathrm{~cm}+\text {, strong brown fine sandy loam }\end{array}$ \\
\hline 96 & $0-100 \mathrm{~cm}+$, strong brown fine sandy loam \\
\hline 97 & $0-52 \mathrm{~cm}+$, dark brown fine sandy loam \\
\hline 98 & 0-18 cm, dark brown fine sandy loam; $18-60 \mathrm{~cm}+$, strong brown fine sandy loam \\
\hline 99 & 0-20 cm, dark brown fine sandy loam; $20-62 \mathrm{~cm}+$, strong brown fine sandy loam \\
\hline 100 & 0-55 $\mathrm{cm}+$, dark brown fine sandy loam \\
\hline 101 & $0-51 \mathrm{~cm}+$, dark brown fine sandy loam \\
\hline 102 & 0-15 cm, dark brown fine sandy loam; $15-62 \mathrm{~cm}+$, strong brown fine sandy loam \\
\hline 103 & 0-10 cm, dark brown fine sandy loam; $10-55 \mathrm{~cm}+$, strong brown fine sandy loam \\
\hline 104 & $0-52 \mathrm{~cm}+$, strong brown fine sandy loam \\
\hline 105 & 0-26 cm, dark brown fine sandy loam; $26-53 \mathrm{~cm}+$, strong brown fine sandy loam \\
\hline 106 & 0-10 $\mathrm{cm}$, dark brown fine sandy loam; $10-56 \mathrm{~cm}+$, strong brown fine sandy loam \\
\hline 107 & $0-46 \mathrm{~cm}+$, strong brown fine sandy loam \\
\hline 111 & $0-58 \mathrm{~cm}+$, strong brown fine sandy loam \\
\hline 114 & 0-60 cm+, dark brown sandy loam \\
\hline 115 & 0-60 cm+, brown fine sandy loam \\
\hline 116 & $0-68 \mathrm{~cm}+$, brown fine sandy loam \\
\hline 129 & 0-50 cm, very dark gray fine sandy loam; $50-56 \mathrm{~cm}+$, brown fine sandy loam \\
\hline 191 & $0-50 \mathrm{~cm}$, dark brown fine sandy loam; $50-57 \mathrm{~cm}+$, strong brown fine sandy loam \\
\hline
\end{tabular}

A total of 480 ceramic vessel sherds and 135 sherdlets were recovered in the shovel tests at the Walnut Branch site (Table 5). The sherdlet/sherd size index is 0.28 . The mean density of sherds is 6.7 sherds per positive shovel test, or ca. 53.6 sherds per square meter of archaeological deposits. The range of sherds by shovel test is 1-26.

Table 5. Ceramic vessel sherds and sherdlets recovered in shovel tests at the Walnut Branch site (41CE47).

\begin{tabular}{lcccc}
\hline ST No. & DS & PS & Sherdlet & $N^{*}$ \\
\hline ST 24 24 & - & 2 & - & 2 \\
ST 25 & 1 & 1 & - & 2 \\
ST 28 & 1 & - & - & 1 \\
ST 29 & 3 & 3 & 1 & 6 \\
ST 30 & 2 & 3 & 1 & 5 \\
ST 31 31 & 1 & 1 & 1 \\
ST 33 & - & 2 & 3 & 6 \\
ST 34 & 4 & 2 & 4 & 5 \\
ST 35 & 3 & 2 & - & 6 \\
ST 36 & 4 & 2 & 2 & 8 \\
ST 37 & 6 & 2 & 1 & 6 \\
ST 38 & - & 3 & - & 6
\end{tabular}


Table 5. Ceramic vessel sherds and sherdlets recovered in shovel tests at the Walnut Branch site (41CE47), cont.

\begin{tabular}{|c|c|c|c|c|}
\hline ST No. & DS & PS & Sherdlet & $\mathrm{N}^{*}$ \\
\hline ST 39 & 4 & 1 & 1 & 5 \\
\hline ST 40 & - & 2 & 1 & 2 \\
\hline ST 42 & - & 1 & 1 & 1 \\
\hline ST 43 & 1 & 1 & - & 2 \\
\hline ST 44 & 3 & 1 & 2 & 4 \\
\hline ST 45 & - & 4 & - & 4 \\
\hline ST 46 & 3 & 4 & 1 & 7 \\
\hline ST 47 & 2 & 2 & 1 & 4 \\
\hline ST 50 & 3 & 1 & 1 & 4 \\
\hline ST 51 & 8 & 2 & 3 & 10 \\
\hline ST 52 & 4 & 3 & - & 7 \\
\hline ST 53 & 15 & 7 & 5 & 22 \\
\hline ST 55 & - & 3 & - & 3 \\
\hline ST 56 & 2 & - & - & 2 \\
\hline ST 57 & 2 & 1 & - & 3 \\
\hline ST 58 & 3 & 1 & 1 & 4 \\
\hline ST 59 & 1 & 1 & - & 2 \\
\hline ST 60 & 1 & 1 & - & 2 \\
\hline ST 61 & 1 & 3 & 1 & 4 \\
\hline ST 62 & 1 & 1 & - & 2 \\
\hline ST 63 & - & 2 & 1 & 2 \\
\hline ST 64 & 2 & - & 1 & 2 \\
\hline ST 65 & - & 1 & 2 & 1 \\
\hline ST 66 & 1 & - & - & 1 \\
\hline ST 67 & 2 & - & 1 & 2 \\
\hline ST 68 & 2 & 1 & 1 & 3 \\
\hline ST 69 & 1 & 1 & - & 2 \\
\hline ST 72 & 1 & 1 & - & 2 \\
\hline ST 75 & 1 & 1 & - & 2 \\
\hline ST 76 & - & 2 & - & 2 \\
\hline ST 77 & 1 & - & - & 1 \\
\hline ST 78 & 1 & - & 1 & 1 \\
\hline ST 79 & 2 & 5 & - & 7 \\
\hline ST 80 & 9 & 7 & 7 & 16 \\
\hline ST 81 & 5 & 1 & 2 & 6 \\
\hline ST 82 & 5 & 6 & 5 & 11 \\
\hline ST 83 & 10 & 6 & 2 & 16 \\
\hline ST 84 & 1 & 3 & 1 & 4 \\
\hline ST 89 & - & 2 & - & 2 \\
\hline ST 90 & 1 & 1 & - & 2 \\
\hline ST 91 & 11 & 7 & 4 & 18 \\
\hline ST 95 & 15 & 9 & 2 & 24 \\
\hline ST 96 & 1 & 1 & - & 2 \\
\hline ST 97 & 14 & 12 & 6 & 26 \\
\hline ST 98 & 8 & 7 & 9 & 15 \\
\hline ST 99 & 2 & 2 & - & 4 \\
\hline ST 100 & 18 & 6 & 4 & 24 \\
\hline ST 101 & 17 & 8 & 10 & 25 \\
\hline ST 102 & 7 & 8 & 6 & 15 \\
\hline
\end{tabular}


Table 5. Ceramic vessel sherds and sherdlets recovered in shovel tests at the Walnut Branch site (41CE47), cont.

\begin{tabular}{lllll}
\hline ST No. & DS & PS & Sherdlet & N* $^{*}$ \\
\hline ST 103 & 13 & 1 & 1 & 14 \\
ST 104 & 9 & 6 & 5 & 15 \\
ST 105 & 6 & 6 & 9 & 12 \\
ST 106 & 4 & - & 4 & 4 \\
ST 107 & 1 & 3 & - & - \\
ST 110 & - & - & 1 & 1 \\
ST 111 & 1 & - & - & 10 \\
ST 114 & 6 & 4 & 5 & 17 \\
ST 115 & 10 & 7 & 8 & 2 \\
ST 116 & 10 & 2 & - & 3 \\
ST 129 & - & 2 & 135 & 480 \\
ST 191 & 1 & 200 & & \\
\hline Totals & 280 & & & \\
\hline
\end{tabular}

DS=decorated sherd; PS=plain sherd

*sherdlets not included in shovel test totals

The shovel tests that have more than 10 sherds cluster in two areas in the central and southern parts of the Walnut Branch site: Cluster A, ca. 26 x 10 m in size, and with ST 51, ST 95, ST 105, and ST 114 (Figure 4), and Cluster B, ca. 26 × $28 \mathrm{~m}$ in size, and with ST 53, ST 80, ST 82, ST 83, ST 91, ST 97, ST 98 , ST 100, ST 101, ST 102, ST 103, ST 104, ST 115, and ST 116. These two spatial artifact clusters likely represent at least 2-3 household compounds with associated extramural activity areas.

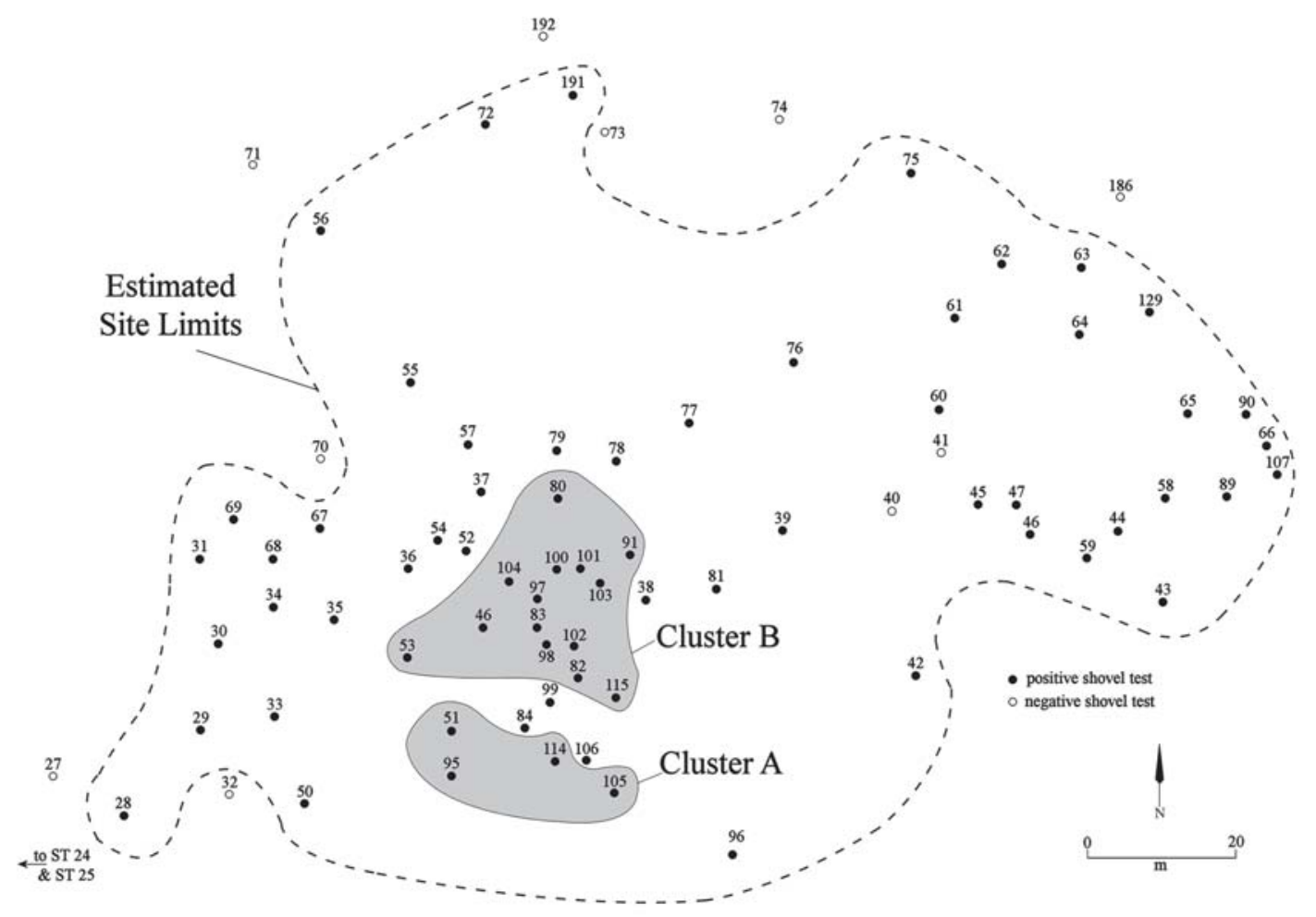

Figure 4. Artifact clusters A and B in the Walnut Branch site. 
A range of other artifacts were recovered in the shovel tests at the Walnut Branch site, particularly burned clay pieces, wood charcoal, lithic debris, ground stone tools, and ceramic elbow pipe sherds (Table 6). Notably, the one lead ball found at the site came from a shovel test just north of Cluster B (see Figure 4). The three ceramic pipe sherds are from Clusters A and B, as are the two chipped stone tools; the ground stone tools are from Cluster B.

Table 6. Other artifacts recovered in the shovel testing at the Walnut Branch site (41CE47).

\begin{tabular}{|c|c|c|c|c|c|c|c|c|c|c|c|}
\hline $\begin{array}{l}\text { ST } \\
\text { No. }\end{array}$ & $\mathrm{BC}$ & WC & NS & $\mathrm{AB}$ & $\mathrm{T}$ & GS & LD & $\begin{array}{l}\text { Pipe } \\
\text { sherd }\end{array}$ & $\begin{array}{l}\text { Coil, } \\
\text { clay }\end{array}$ & LB & $\mathrm{N}$ \\
\hline 23 & & 2 & & & & & & & & & 2 \\
\hline 34 & 2 & & & & & & & & & & 2 \\
\hline 35 & 1 & & & & & & 1 & & & & 2 \\
\hline 36 & 1 & & & & & & & & & & 1 \\
\hline 42 & & & & & & & 1 & & & & 1 \\
\hline 43 & & 3 & & & & & & & & & 3 \\
\hline 53 & 1 & & & & & 1 & 1 & & 1 & & 4 \\
\hline 57 & & & & & & & 1 & & & & 1 \\
\hline 58 & 2 & & & 1 & & & 1 & & & & 4 \\
\hline 61 & & & & & & & 1 & & & & 1 \\
\hline 63 & 1 & & & & & & & & & & 1 \\
\hline 65 & 1 & & & & & & & & & & 1 \\
\hline 78 & & & & & & & & & & 1 & 1 \\
\hline 80 & & 4 & & & & & 1 & & & & 5 \\
\hline 82 & & & & & & & & 1 & & & 1 \\
\hline 83 & & 2 & & 1 & & & 1 & & & & 4 \\
\hline 89 & & & & & & 1 & & & & & 1 \\
\hline 95 & & & 1 & & & & & & & & 1 \\
\hline 97 & & & & & & 1 & & & & & 1 \\
\hline 102 & & & & & & 1 & & & & & 1 \\
\hline 105 & & & & & & & & & 1 & & 1 \\
\hline 110 & & 3 & & & & & & & & & 3 \\
\hline 114 & 1 & & & & 1 & & & 1 & & & 3 \\
\hline 115 & & & & 1 & & & & & & & 1 \\
\hline 116 & & 1 & & & 1 & & & 1 & & & 3 \\
\hline Totals & 10 & 15 & 1 & 3 & 2 & 4 & 9 & 3 & 2 & 1 & 50 \\
\hline
\end{tabular}

$\mathrm{BC}=$ burned clay; $\mathrm{WC}=$ wood charcoal; $\mathrm{NS}=$ nutshell; $\mathrm{AB}=$ animal bone; $\mathrm{T}=$ chipped stone tool; $\mathrm{GS}=$ ground stone, including red ochre piece and polished pebble; $\mathrm{LB}=$ lead ball

\section{Ross I (41CE485)}

At the Ross I site, shovel testing determined that the site covers a ca. 104 x $60 \mathrm{~m}$ area, or ca. 1.5 acres (Figure 5). A total of 31 positive shovel tests were excavated on the site (Table 7), or ca. 20.7 positive shovel tests per acre of the site. The sediments are a fine sandy loam that ranges from $42 \mathrm{~cm}$ to $80 \mathrm{~cm}$ in thickness overlying a clay B-horizon in the deeper shovel tests; the sediments were very moist. One shovel test (ST 179) encountered a probable feature between $50-60 \mathrm{~cm}$ bs: a $10 \mathrm{~cm}$ thick lens of charcoal and ash. 


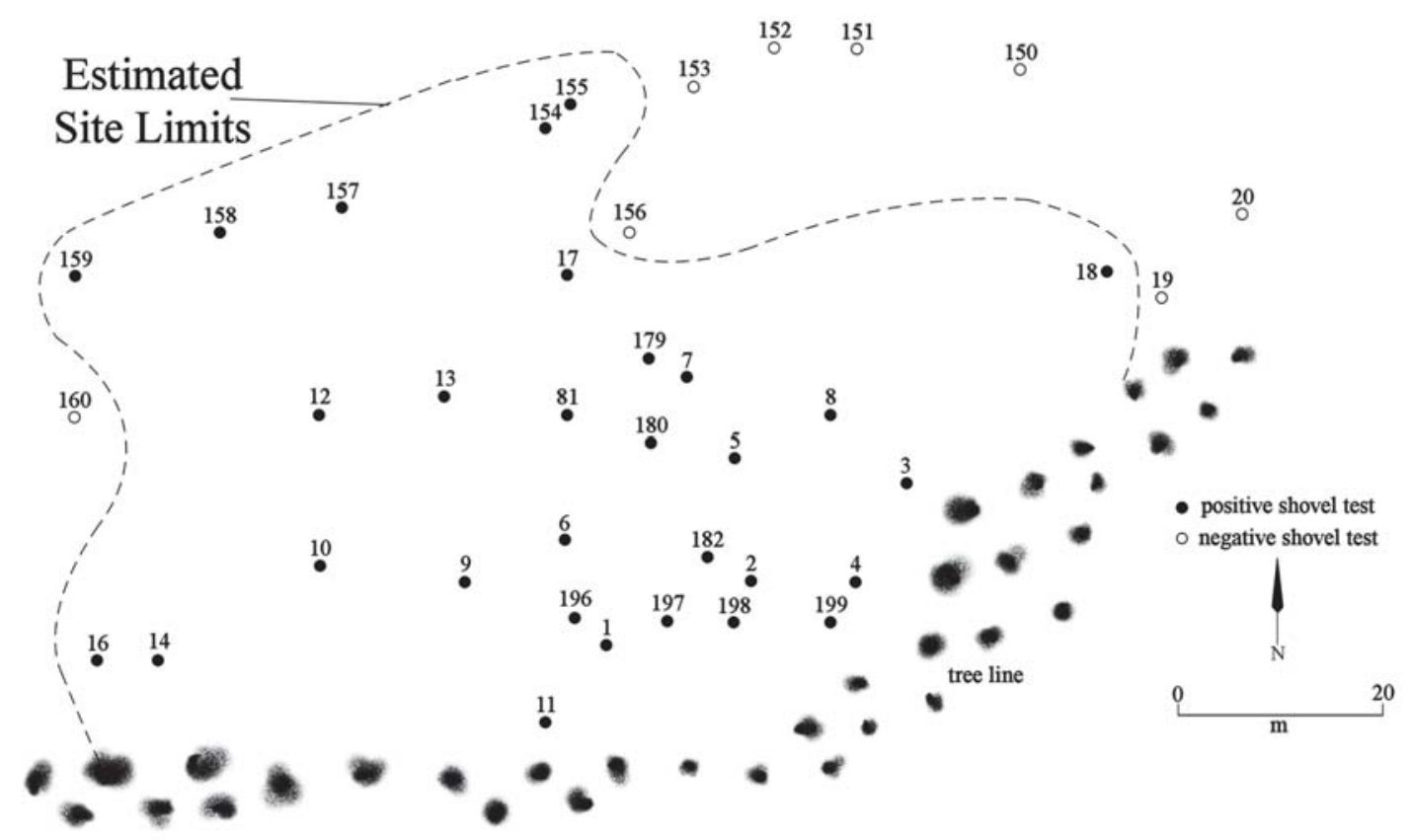

Figure 5. Map of the Ross I site (41CE485).

Table 7. Sediment descriptions in positive shovel tests at the Ross I site (41CE485).

No.

Sediment description

0-10 cm, dark gray fine sandy loam; $10-43 \mathrm{~cm}+$, brown fine sandy loam

$0-10 \mathrm{~cm}$, dark gray fine sandy loam; $10-48 \mathrm{~cm}+$, brown fine sandy loam

0-10 cm, dark gray fine sandy loam; $10-45 \mathrm{~cm}+$, brown fine sandy loam

0-10 cm, dark gray fine sandy loam; $10-43 \mathrm{~cm}+$, brown fine sandy loam

0-10 cm, dark gray fine sandy loam; $10-47 \mathrm{~cm}+$, brown fine sandy loam

$0-10 \mathrm{~cm}$, dark gray fine sandy loam; $10-51 \mathrm{~cm}+$, brown fine sandy loam

$0-10 \mathrm{~cm}$, dark gray fine sandy loam; $10-52 \mathrm{~cm}+$, brown fine sandy loam

$0-10 \mathrm{~cm}$, dark gray fine sandy loam; $10-43 \mathrm{~cm}+$, brown fine sandy loam

$0-53 \mathrm{~cm}+$, strong brown fine sandy loam

$0-46 \mathrm{~cm}+$, strong brown fine sandy loam

$0-50 \mathrm{~cm}+$, strong brown fine sandy loam

$0-47 \mathrm{~cm}^{+}$, brown fine sandy loam

$0-52 \mathrm{~cm}+$, brown fine sandy loam

$0-48 \mathrm{~cm}+$, brown fine sandy loam

$0-54 \mathrm{~cm}+$, brown fine sandy loam

$0-52 \mathrm{~cm}+$, brown fine sandy loam

0-10 cm, dark gray fine sandy loam; $10-46 \mathrm{~cm}+$, brown fine sandy loam

$0-58 \mathrm{~cm}+$, strong brown fine sandy loam

$0-42 \mathrm{~cm}+$, strong brown fine sandy loam

$0-53 \mathrm{~cm}+$, strong brown fine sandy loam

$0-38 \mathrm{~cm}+$, strong brown fine sandy loam

$0-53 \mathrm{~cm}+$, strong brown fine sandy loam

$0-61 \mathrm{~cm}+$, strong brown fine sandy loam

0-50 cm, dark brown fine sandy loam and gray fine sandy loam; $50-60 \mathrm{~cm}$, ash and charcoal lens; $60-68 \mathrm{~cm}+$, brown clay

180

$0-80 \mathrm{~cm}$, strong brown fine sandy loam; $80-88 \mathrm{~cm}+$, dark brown clay with gray mottles

0-60 cm, strong brown fine sandy loam; $60-66 \mathrm{~cm}+$, reddish-yellow clay with gray mottles 
Table 7. Sediment descriptions in positive shovel tests at the Ross I site (41CE485), cont.

\begin{tabular}{ll} 
No. & Sediment description \\
\hline 182 & $0-70 \mathrm{~cm}$, dark brown fine sandy loam; $70-74 \mathrm{~cm}+$, reddish-yellow clay with gray mottles \\
196 & $0-10 \mathrm{~cm}$, dark gray fine sandy loam; $10-43 \mathrm{~cm}+$, brown fine sandy loam \\
197 & $0-10 \mathrm{~cm}$, dark gray fine sandy loam; $10-48 \mathrm{~cm}+$, brown fine sandy loam \\
198 & $0-10 \mathrm{~cm}$, dark gray fine sandy loam; $10-57 \mathrm{~cm}+$, brown fine sandy loam \\
199 & $0-10 \mathrm{~cm}$, dark gray fine sandy loam; $10-50 \mathrm{~cm}+$, brown fine sandy loam
\end{tabular}

Ceramic vessel sherds and sherdlets recovered in the shovel tests at the Ross I site are listed in Table 8. The mean density of sherds per shovel test is 7.0 (or ca. 56.0 sherds per square meter of archaeological deposits), with a range of 1-30 sherds. The proportion of sherdlets to sherds, or a sherd size index (cf. Fitts 2017:174-175), is 0.22 .

Table 8. Ceramic vessel sherds and sherdlets from shovel tests at the Ross I site (41CE485).

\begin{tabular}{|c|c|c|c|c|}
\hline Shovel Test No. & DS & PS & Sherdlets & $\mathrm{N}^{*}$ \\
\hline ST 1 & 2 & 2 & 1 & 4 \\
\hline ST 2 & 5 & 1 & - & 6 \\
\hline ST 3 & 2 & 1 & - & 3 \\
\hline ST 4 & 9 & 6 & - & 15 \\
\hline ST 5 & 6 & 4 & - & 10 \\
\hline ST 6 & 7 & - & - & 7 \\
\hline ST 7 & 8 & 7 & - & 15 \\
\hline ST 8 & 4 & 4 & - & 8 \\
\hline ST 9 & 5 & 5 & - & 10 \\
\hline ST 10 & 3 & 5 & - & 8 \\
\hline ST 11 & 1 & 2 & - & 3 \\
\hline ST 12 & 4 & 2 & - & 6 \\
\hline ST 13 & 2 & 2 & - & 4 \\
\hline ST 14 & - & 1 & - & 1 \\
\hline ST 15 & - & 1 & - & 1 \\
\hline ST 16 & - & 1 & - & 1 \\
\hline ST 17 & 2 & 3 & - & 5 \\
\hline ST 18 & 5 & - & - & 5 \\
\hline ST 154 & - & 1 & - & 1 \\
\hline ST 155 & 1 & - & - & 1 \\
\hline ST 157 & - & 1 & - & 1 \\
\hline ST 158 & 1 & 1 & - & 2 \\
\hline ST 159 & 3 & 5 & 7 & 8 \\
\hline ST 179 & 2 & 3 & 1 & 5 \\
\hline ST 180 & 2 & 5 & 3 & 7 \\
\hline ST 181 & 1 & 5 & 3 & 6 \\
\hline ST 182 & 5 & 1 & 10 & 6 \\
\hline ST 196 & 7 & 7 & 10 & 14 \\
\hline ST 197 & 8 & 6 & 8 & 14 \\
\hline ST 198 & 2 & 3 & 2 & 5 \\
\hline ST 199 & 18 & 12 & 3 & 30 \\
\hline Totals & 116 & 101 & 48 & 217 \\
\hline
\end{tabular}

*does not include sherdlets; DS=decorated sherd; PS=plain sherd 
Seven of the positive shovel tests at the Ross I site have between 10-30 sherds per shovel test (see Figure 5). They cluster into three areas in a ca. $30 \times 30 \mathrm{~m}$ area in the central and southern part of the site: Cluster A, with ST 4 and ST 199; Cluster B, with ST 9, ST 196, and ST 197; and Cluster C, with ST 5 and 7. ST 179 with the possible feature also falls in cluster C. These three clusters likely represent Caddo house compounds with an open plaza or work areas between them (Figure 6).

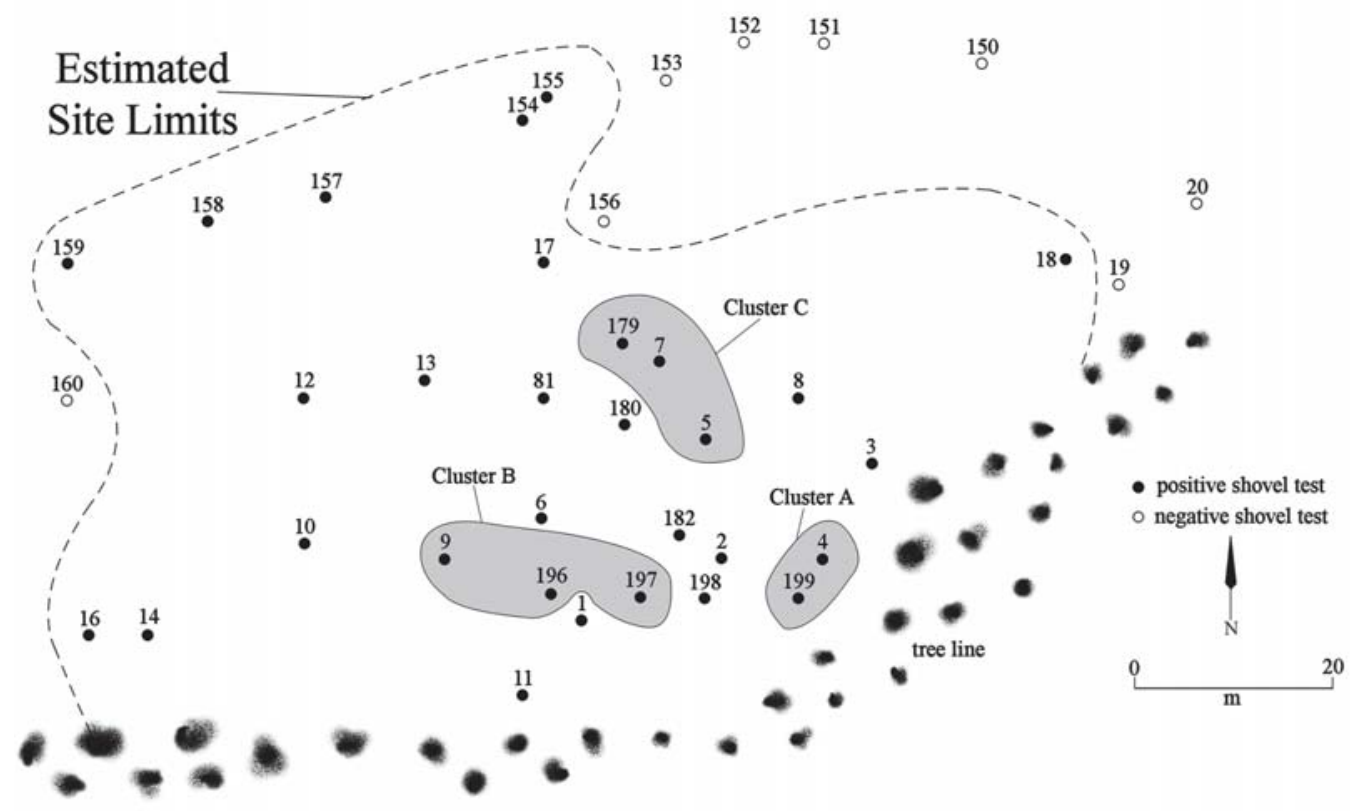

Figure 6. Clusters A-C at the Ross I site (41CE485).

There are a few other kinds of artifacts recovered in the shovel testing at the Ross I site (Table 9), principally burned clay (possibly remnants of hearths or earth ovens) and animal bones. The one ceramic elbow pipe sherd is in Cluster A, and animal bone primarily occurs in Clusters A and B, or not far from Cluster A, as does nutshell. Most of the burned clay pieces also are present in one or another of the clusters, except for the burned clay from ST 154 and ST 158 at the northern end of the site (see Figure 5); wood charcoal pieces also are present in this part of the site.

Table 9. Other artifacts recovered in shovel testing at the Ross I site (41CE485).

\begin{tabular}{|c|c|c|c|c|c|c|}
\hline ST No. & $\begin{array}{l}\text { Pipe } \\
\text { Sherd }\end{array}$ & $\mathrm{BC}$ & WC & NS & $\mathrm{AB}$ & $\mathrm{N}$ \\
\hline ST 3 & & 1 & & & 3 & 4 \\
\hline ST 4 & & & & 4 & 3 & 7 \\
\hline ST 154 & & 2 & & & & 2 \\
\hline ST 158 & 1 & & & & & 1 \\
\hline ST 159 & & & 2 & & & 2 \\
\hline ST 179 & & 4 & & & & 4 \\
\hline ST 181 & & 3 & & & & 3 \\
\hline ST 196 & & 2 & & & 2 & 4 \\
\hline ST 199 & 1 & & & & & 1 \\
\hline Totals & 1 & 13 & 2 & 4 & 8 & 28 \\
\hline
\end{tabular}

$\mathrm{BC}=$ burned clay; $\mathrm{WC}=$ wood charcoal; $\mathrm{NS}=$ nutshell; $\mathrm{AB}=$ animal bone 


\section{Ross II (41CE486)}

Shovel testing at the Ross II site determined that the site is ca. $106 \times 76 \mathrm{~m}$ in size, or ca. 2.0 acres (Figure 7); a small $14 \times 16 \mathrm{~m}$ area at the southeastern end of the site is referred to as Area A. A total of 36 shovel tests at the site had cultural materials (Table 10), which amounts to 18.0 shovel tests per acre of the site. The sediments are a fine sandy loam that ranges in color from strong brown to dark brown, and from 34-100+ cm bs. Where encountered, the clay B-horizon is either a strong brown or reddish-yellow color. No apparent cultural features were encountered in any of the shovel tests at the Ross II site.

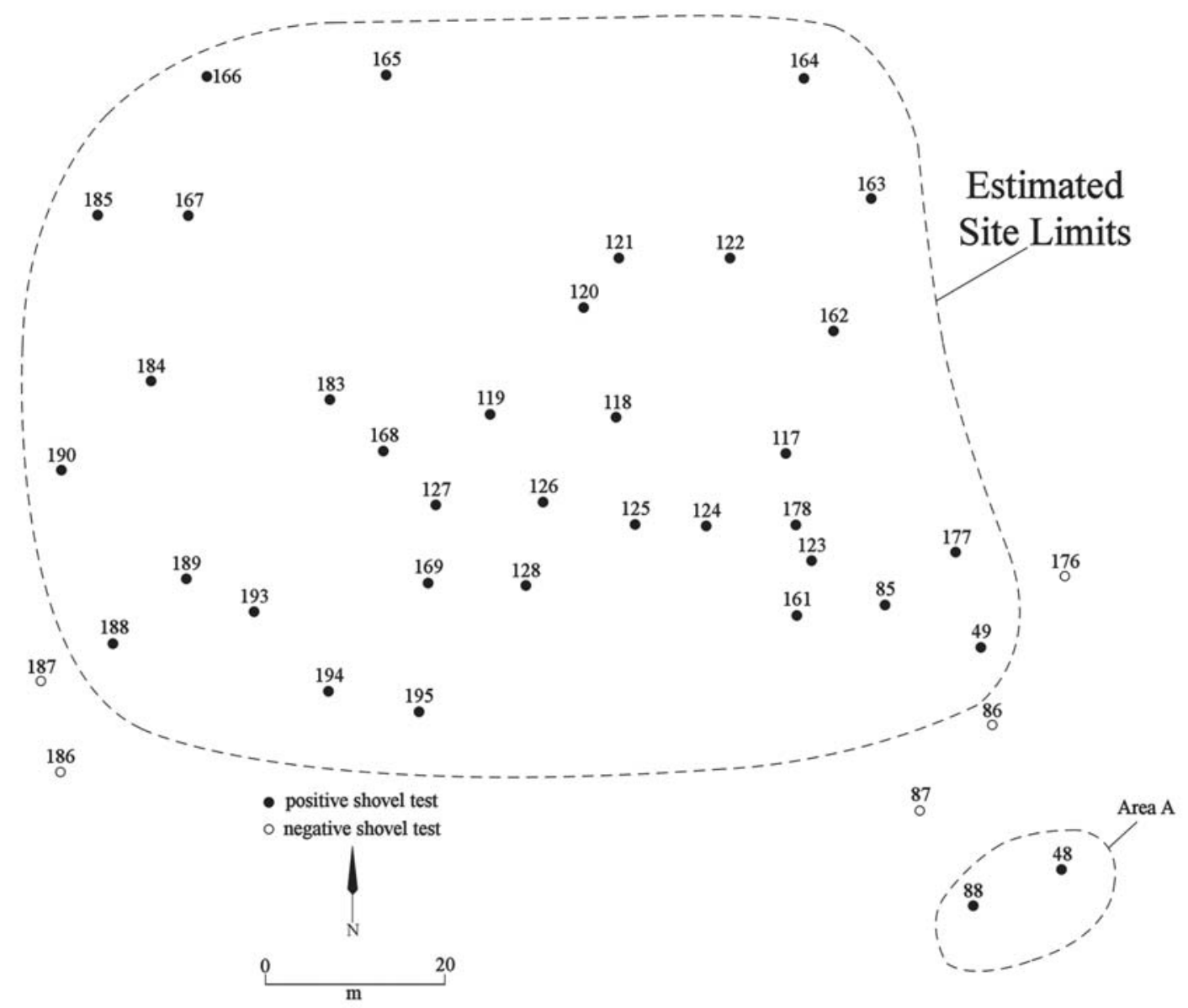

Figure 7. Map of the Ross II site (41CE486).

Table 10. Sediment descriptions in positive shovel tests at the Ross II site (41CE486).

No.

Sediment description

48

49

85

88

117

118

119

120

121
$0-78 \mathrm{~cm}+$, brown fine sandy loam

$0-52 \mathrm{~cm}$, brown fine sandy loam; $52 \mathrm{~cm}+$, strong brown clay

0-100 $\mathrm{cm}+$, strong brown fine sandy loam

0-100 cm + , strong brown fine sandy loam

$0-100 \mathrm{~cm}+$, brown fine sandy loam

0-38 cm, dark brown fine sandy loam; 38-43 cm+, reddish-yellow clay

0-36 cm, dark brown fine sandy loam; 36-40 cm+, reddish-yellow clay

0-78 cm, strong brown fine sandy loam; 78-80 cm+, reddish-yellow clay

0-54 cm, strong brown fine sandy loam; 54-56 cm+, reddish-yellow clay 
Table 10. Sediment descriptions in positive shovel tests at the Ross II site (41CE486), cont.

\begin{tabular}{|c|c|}
\hline No. & Sediment description \\
\hline 122 & 0-61 cm, strong brown fine sandy loam; 61-65 cm+, reddish-yellow clay \\
\hline 123 & $0-68 \mathrm{~cm}$, brown fine sandy loam; $68-72 \mathrm{~cm}+$, reddish-yellow clay \\
\hline 124 & 0-38 cm, brown fine sandy loam; $38-42 \mathrm{~cm}+$, reddish-yellow clay \\
\hline 125 & 0-40 cm, dark brown fine sandy loam; $40-44 \mathrm{~cm}+$, reddish-yellow clay \\
\hline 126 & 0-40 cm, dark brown fine sandy loam; $40-43 \mathrm{~cm}+$, reddish-yellow clay \\
\hline 127 & 0-58 cm, brown fine sandy loam; $58-62 \mathrm{~cm}+$, reddish-yellow clay \\
\hline 128 & 0-45 cm, brown fine sandy loam; $45-47 \mathrm{~cm}+$, reddish-yellow clay \\
\hline 161 & 0-55 cm, strong brown fine sandy loam; $55-58 \mathrm{~cm}+$, strong brown clay \\
\hline 162 & $0-100 \mathrm{~cm}+$, brown fine sandy loam; thin layer of charcoal at ca. $78 \mathrm{~cm} \mathrm{bs}$ \\
\hline 163 & $0-93 \mathrm{~cm}+$, brown fine sandy loam \\
\hline 164 & 0-75 cm, brown fine sandy loam; $75-78 \mathrm{~cm}+$, strong brown clay \\
\hline 165 & 0-34 cm, dark brown fine sandy loam; $34-36 \mathrm{~cm}+$, strong brown clay \\
\hline 166 & $0-67 \mathrm{~cm}+$, strong brown fine sandy loam \\
\hline 167 & $0-45 \mathrm{~cm}$, brown fine sandy loam; $45-48 \mathrm{~cm}+$, strong brown clay \\
\hline 168 & 0-45 cm, brown fine sandy loam; $45-47 \mathrm{~cm}+$, strong brown clay \\
\hline 169 & $\begin{array}{l}0-25 \mathrm{~cm} \text {, brown fine sandy loam; } 25-65 \mathrm{~cm} \text {, very dark gray fine sandy loam; } 65-73 \mathrm{~cm}+\text {, } \\
\text { brown fine sandy loam }\end{array}$ \\
\hline 177 & 0-45 cm, brown fine sandy loam; $45-48 \mathrm{~cm}+$, strong brown clay \\
\hline 178 & $0-85 \mathrm{~cm}$, brown fine sandy loam; $85-88 \mathrm{~cm}+$, strong brown clay \\
\hline 183 & 0-90 cm, brown fine sandy loam; $90-95 \mathrm{~cm}+$, reddish-yellow clay \\
\hline 184 & 0-98 cm+, brown fine sandy loam \\
\hline 185 & $0-68 \mathrm{~cm}+$, brown fine sandy loam \\
\hline 188 & $0-60 \mathrm{~cm}$, dark brown fine sandy loam; $60-66 \mathrm{~cm}+$, brown clay \\
\hline 189 & $0-70 \mathrm{~cm}$, strong brown fine sandy loam; $70-73 \mathrm{~cm}+$, dark brown clay with gray mottles \\
\hline 190 & $0-65 \mathrm{~cm}$, dark brown fine sandy loam; $65-68 \mathrm{~cm}+$, strong brown clay \\
\hline 193 & $\begin{array}{l}\text { 0-62 cm, dark brown fine sandy loam; } 62-72 \mathrm{~cm} \text {, strong brown fine sandy loam; } 72-75 \\
\mathrm{~cm}+\text {, strong brown clay }\end{array}$ \\
\hline 194 & $0-56 \mathrm{~cm}+$, dark brown fine sandy loam \\
\hline 195 & $0-51 \mathrm{~cm}+$, dark brown fine sandy loam \\
\hline
\end{tabular}

The shovel tests at the Ross II site recovered 237 ceramic vessel sherds and 134 sherdlets (Table 11); the sherdlet/sherd index is 0.57 , much higher than at the Ross I site. The mean sherd density is 6.6 sherds per positive shovel test, with a range of 1-17 sherds per shovel test, or ca 52.8 sherds per square meter of archaeological deposits at the site.

Table 11. Ceramic vessel sherds and sherdlets from the Ross II site (41CE486) shovel testing.

\begin{tabular}{lllll}
\hline Shovel Test No. & DS & PS & Sherdlet & $N^{*}$ \\
\hline ST 48 & 4 & 2 & 1 & 6 \\
ST 49 & 3 & - & - & 3 \\
ST 85 & 1 & 2 & - & 3 \\
ST 117 & 5 & 2 & 1 & 7 \\
ST 118 & 5 & 7 & 12 & 12 \\
ST 119 & 3 & 4 & 11 & 7 \\
ST 120 & 10 & 7 & 13 & 17 \\
ST 121 & 1 & 3 & 1 & 4 \\
ST 122 & 1 & 3 & 2 & 4
\end{tabular}


Table 11. Ceramic vessel sherds and sherdlets from the Ross II site (41CE486) shovel testing, cont.

\begin{tabular}{|c|c|c|c|c|}
\hline Shovel Test No. & DS & PS & Sherdlet & $\mathrm{N}^{*}$ \\
\hline ST 123 & - & 3 & 3 & 3 \\
\hline ST 124 & 1 & 2 & 5 & 3 \\
\hline ST 125 & 7 & 4 & 5 & 11 \\
\hline ST 126 & 8 & 7 & 5 & 15 \\
\hline ST 127 & 3 & 2 & 4 & 5 \\
\hline ST 128 & 1 & 4 & 8 & 5 \\
\hline ST 161 & 1 & 2 & 2 & 3 \\
\hline ST 162 & 5 & 1 & 7 & 6 \\
\hline ST 163 & 4 & 7 & 2 & 11 \\
\hline ST 164 & 3 & - & 1 & 3 \\
\hline ST 165 & 1 & 6 & 5 & 7 \\
\hline ST 166 & 5 & 4 & 2 & 9 \\
\hline ST 167 & - & 3 & 2 & 3 \\
\hline ST 168 & 2 & 11 & - & 13 \\
\hline ST 169 & - & 3 & 3 & 3 \\
\hline ST 177 & 1 & - & - & 1 \\
\hline ST 178 & - & 2 & - & 2 \\
\hline ST 183 & 9 & 6 & 10 & 15 \\
\hline ST 184 & 3 & 1 & 8 & 4 \\
\hline ST 185 & 8 & 6 & 14 & 14 \\
\hline ST 188 & 6 & 2 & 2 & 8 \\
\hline ST 189 & 3 & 5 & 2 & 8 \\
\hline ST 190 & 1 & - & - & 1 \\
\hline ST 193 & 5 & 5 & - & 10 \\
\hline ST 194 & 4 & 3 & 3 & 7 \\
\hline ST 195 & - & 1 & - & 1 \\
\hline Totals & 116 & 121 & 134 & 237 \\
\hline
\end{tabular}

$\mathrm{DS}=$ decorated sherd; $\mathrm{PS}=$ plain sherd

*sherdlets not included in totals

The density of sherds in the shovel tests at the Ross II site represent two spatial clusters in the center of the landform, Cluster A, with ST 118, ST 120, ST 125, and ST 126, and Cluster B with ST 168 and ST 183 (Figure 8). These likely represent areas with one or two household compounds and a plaza or extramural work areas between. There are single shovel tests located northeast (ST 163), southwest (ST193), and northwest (ST 185) that have high sherd densities; they may also represent locations of more far removed extramural work areas.

The one pipe sherd from the Ross II site is in a small cluster (ST 185) northwest of the principal proposed household compounds (see Figure 8). The burned clay pieces occur mainly in and around Cluster A and B, as does some of the wood charcoal and animal bone (Table 12). The lithic debris is present in and amongst Clusters A and B, suggesting that some lithic tool manufacture occurred in the proposed household compounds. One ground stone tool is in a small cluster (ST 163) northeast of Clusters A and B, while the other is in a shovel test at the western end of the site. Finally, the lead ball is from ST 163 northeast of Clusters A and B (see Figure 8). 


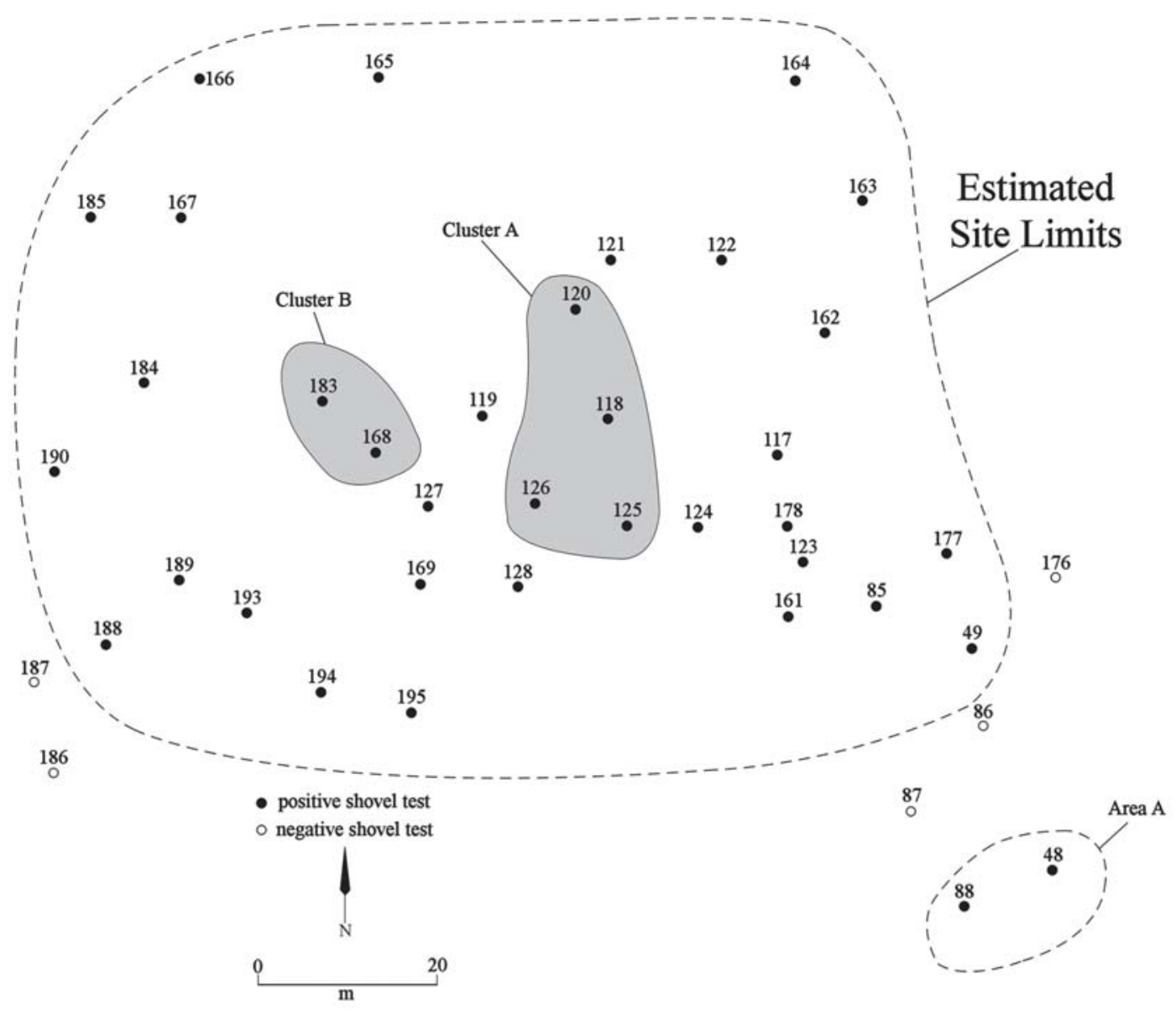

Figure 8. Clusters A and B, and miscellaneous small clusters, in the Ross II site (41CE486).

Table 12. Other artifacts recovered in shovel testing at the Ross II site (41CE486).

\begin{tabular}{|c|c|c|c|c|c|c|c|c|}
\hline ST No. & $\begin{array}{l}\text { Pipe } \\
\text { Sherd }\end{array}$ & $\mathrm{BC}$ & WC & $\mathrm{AB}$ & LD & GS & $\begin{array}{l}\text { Lead } \\
\text { Ball }\end{array}$ & $\mathrm{N}$ \\
\hline ST 88 & & & & & 1 & & & 1 \\
\hline ST 118 & & & & & 2 & & & 2 \\
\hline ST 119 & & 1 & & & & & & 1 \\
\hline ST 120 & & & 2 & 1 & 1 & & & 4 \\
\hline ST 121 & & 1 & & & 1 & & & 2 \\
\hline ST 125 & & & & & 1 & & & 1 \\
\hline ST 126 & & 1 & & & & & & 1 \\
\hline ST 127 & & 1 & & & & & & 1 \\
\hline ST 163 & & & & 1 & & 1 & 1 & 3 \\
\hline ST 165 & & 1 & & & & & & 1 \\
\hline ST 178 & & & 2 & & & & & 2 \\
\hline ST 183 & & 1 & & & 2 & & & 3 \\
\hline ST 184 & & & & & 1 & & & 1 \\
\hline ST 185 & 1 & & & & 1 & & & 2 \\
\hline ST 190 & & 1 & & & & 1 & & 2 \\
\hline Totals & 1 & 7 & 4 & 2 & 10 & 2 & 1 & 27 \\
\hline
\end{tabular}

$\mathrm{BC}=$ burned clay; $\mathrm{WC}=$ wood charcoal; $\mathrm{AB}=$ animal bone; $\mathrm{LD}=$ lithic debris; $\mathrm{GS}=$ ground stone tool 


\section{Archaeological Materials Recovered at the Sites}

A wide range of archaeological materials were recovered in the surface collections and intensive shovel testing at the Walnut Branch (41CE47), John Ross I (41CE485), and John Ross II (41CE486) sites. Not counting the several hundred sherdlets $(<1.5 \mathrm{~cm}$ in diameter), this includes 1068 plain and decorated ceramic vessel sherds (representing 91 percent of the artifact assemblage), ceramic elbow pipe sherds $(n=5)$, clay coils $(n=2)$, burned clay pieces $(n=30)$, chipped stone tools $(n=2)$, lithic debris $(n=21)$, ground stone tools $(n=7)$, early $18^{\text {th }}$ century lead balls $(n=2)$, wood charcoal $(n=21)$, charred nutshells $(n=5)$, and animal bone $(n=13)$. Each of these categories of recovered archaeological materials are discussed below, beginning with the ancestral Caddo ceramic vessel sherds.

\section{Ceramic vessel sherds}

A total of 1068 ceramic vessel sherds have been collected in the 2017 archaeological investigations at the Walnut Branch (41CE47), John Ross I (41CE485), and John Ross II (41CE486) sites along Walnut Branch, including ceramic vessel sherds found on the surface of the Walnut Branch stream bed. This includes 477 plain rim, body, and base sherds, and 591 decorated rim and body sherds (Table 13). The composite plain to decorated sherd ratio (P/DR) for the assemblage is 0.81 , but the P/DR ranges from 0.68 for the surface collection materials, 0.71 at the Walnut Branch site, 0.87 at the John Ross I site, and 1.06 at the John Ross II site. The P/DR values at these sites are considerably higher than they are at contemporaneous Allen phase sites in the Neche cluster on Bowles Creek (Perttula 2017a), where P/DR values are less than 0.40 ; we will return to this topic in the concluding section of the article.

Table 13. Plain and decorated ceramic vessel sherds from the sites along Walnut Branch in Cherokee County, Texas.

\begin{tabular}{lllll}
\hline Decorative method & CE485 & CE486 & CE47 & Surface \\
\hline Plain & 101 & 114 & 200 & 55
\end{tabular}

\section{Utility ware}

Appliqued

Brushed

Brushed-Appliqued

Brushed-Incised

Brushed-Incised-Appliqued

Brushed-Incised-Punctated

Brushed-Punctated

Grooved

Grooved-Brushed

Grooved-Incised

Incised

Incised-Punctated

Pinched

Tool Punctated

Subtotal, Utility ware
43

40

$-$

1

5

2

$-$

12

4

$-$

1

108

114

\section{Fine ware}

\begin{tabular}{lllll} 
Engraved & 8 & 6 & 34 & 16 \\
Engraved-Brushed & - & - & 1 & - \\
Subtotal, Fine ware & 8 & 6 & 35 & 16 \\
\hline Totals & 217 & 235 & 480 & 136 \\
\hline
\end{tabular}


Just as the proportion of plain to decorated sherds differs among the three sites, so too are there differences in the proportions of utility ware versus fine ware, as well as differences in the relative frequency of the difference decorative methods. The highest proportion of fine ware sherds is at the Walnut Branch site (12.5 percent), compared to only 5.3-6.9 percent at the John Ross I and John Ross II sites; the latter two sites have the highest proportion of utility ware sherds (93.1-94.7 percent) in the decorated sherd assemblage. Among the fine wares are sherds of Patton Engraved, Poynor Engraved (at the John Ross I site), and Mayhew Rectilinear (Figure 9); there are no clear examples of King Engraved in the assemblages.

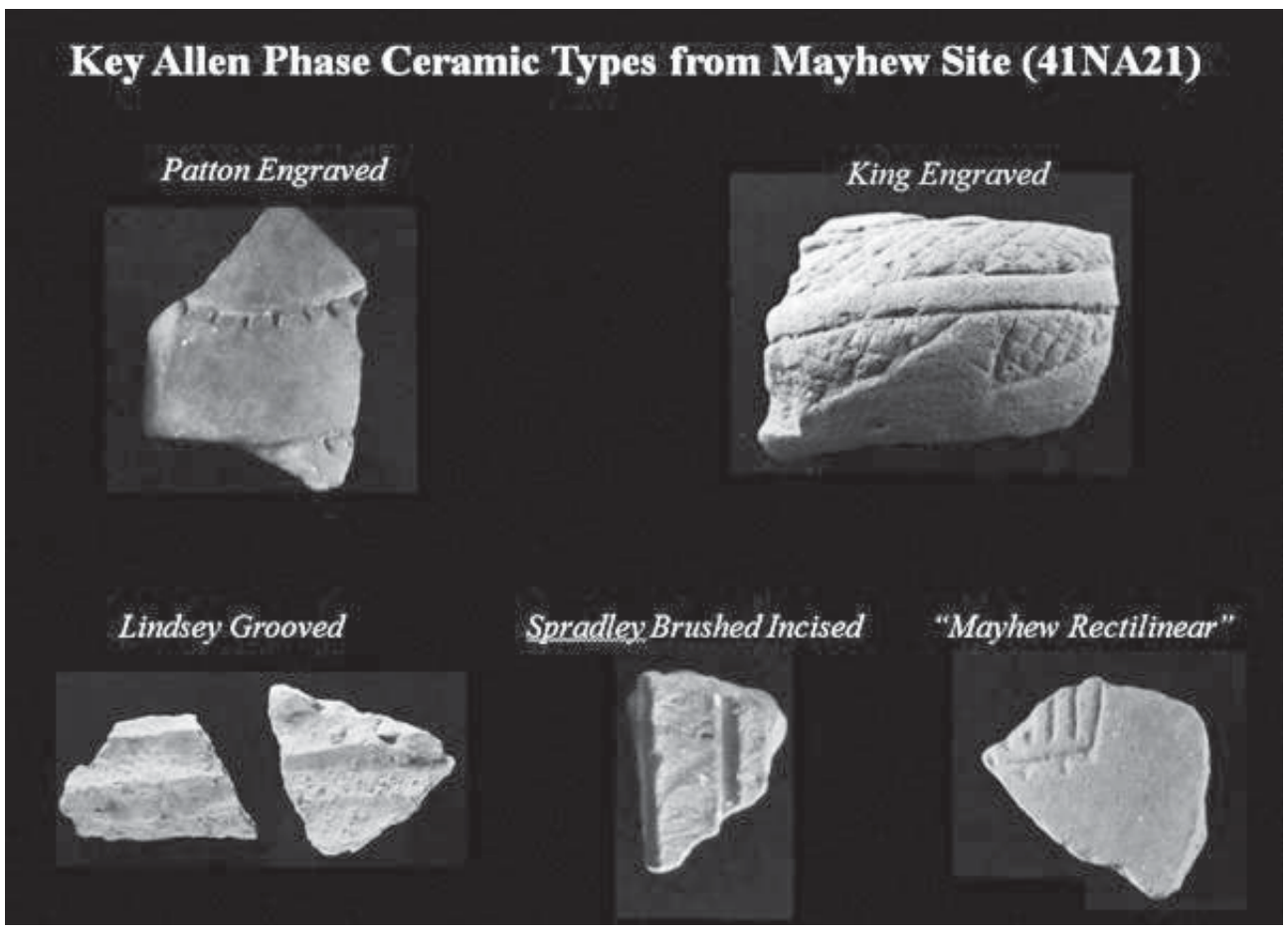

Figure 9. Key Allen phase ceramic types from the Mayhew site (41NA21). Figure provided courtesy of Tom Middlebrook.

Sherds from vessels with brushing marks comprise 67.3 percent of the decorated sherds at the Walnut Branch site compared to 76.8 percent at the John Ross I site and 72.0 percent at the John Ross II site (see Table 13). These sherds are from Bullard Brushed vessels. It is likely that there was a gradual diminishment of the use of brushing as a decorative method in post-A.D. 1680 sites in this area, or a different overall decorative assemblage character and composition when compared to the Neche/Bowles Creek cluster of Allen phase sites.

Brushed-punctated sherds, also from Bullard Brushed vessels, are most abundant at the John Ross I site (5.2 percent), while sherds from Lindsey Grooved (see Figure 9) vessels are best represented at the John Ross II site (2.7 percent), but 2.5 percent of the sherds at the Walnut Branch site has the distinctive grooves of Lindsey Grooved vessels. One sherd from the John Ross I site may be from a Spradley Brushed-Incised vessel (see Figure 9). Sherds with incised and appliqued decorative elements are also best represented at the John Ross II site (2.7 percent and 1.8 percent, respectively). In addition to the higher frequencies of engraved and engraved-brushed sherds at the Walnut Branch site, also best represented in this ceramic assemblage are sherds with tool punctations ( 3.9 percent), brushed-appliqued ( 0.4 percent), and brushed-appliqued-incised (0.4 percent) decorative methods (see Table 13).

\section{Surface Collection, 41CE47/41CE485}

The 55 plain sherds in the surface collection from the stream bed adjacent to the Walnut Branch (41CE47) and John Ross I (41CE485) sites include a plain rim from a bottle, 48 body sherds, and six 
base sherds. The 81 decorated sherds from the surface collection are characterized by ware, decorative method, decorative element, and rim or body sherd (Table 14).

Table 14. Decorative methods and elements in the decorated sherds from the surface collection of the Walnut Branch stream bed by the Walnut Branch and John Ross I sites.

\begin{tabular}{llll}
\hline Decorative method and element & Rim & Body & $N$ \\
\hline
\end{tabular}

\section{$\underline{\text { Utility Ware }}$}

\section{Brushed}

horizontal brushed

opposed brushed marks

parallel brushed marks

$\begin{array}{lll}2 * & - & 2 \\ - & 3 & 3 \\ - & 24 & 24\end{array}$

Brushed-Incised

diagonal brushed-incised marks and lines

opposed brushed-incised marks and lines

overlapping brushed-incised marks and lines

parallel brushed-incised marks and lines

$\begin{array}{lll} & & \\ - & 1 & 1 \\ - & 3 & 3 \\ - & 1 & 1 \\ - & 22 & 22\end{array}$

Brushed-Punctated

horizontal brushed [rim], fingernail punctated row at rim-body

juncture, and vertical brushed on the body

horizontal brushed and tool punctated row below the lip

\section{Grooved}

parallel grooves

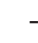

Incised

parallel incised lines

straight incised line

Incised-Punctated

tool punctated row below lip and above horizontal incised line

\section{Punctated}

tool punctated row/rows below the lip

\section{Fine Ware}

\section{Engraved}

horizontal engraved line below the lip

horizontal engraved line

horizontal and curvilinear engraved lines with

triangular tick marks and hatched triangle el. $* *$

horizontal engraved line and vertical columns

opposed curvilinear engraved lines

parallel engraved lines

straight engraved line with triangular tick marks

straight engraved lines

straight and curvilinear engraved lines

\begin{tabular}{lll}
1 & - & 1 \\
- & 1 & 1 \\
1 & - & 1 \\
- & 1 & 1 \\
- & 1 & 1 \\
- & 3 & 3 \\
- & 1 & 1 \\
- & 4 & 4 \\
- & 2 & 2 \\
\hline 9 & 72 & 81 \\
\hline
\end{tabular}

Totals

*one rim has rim peaks

**Patton Engraved, var. Walnut Branch 
About 80 percent of the decorated sherds in the surface collection are from utility wares, primarily from Bullard Brushed sherds; the incised and incised-punctated sherds are likely from Maydelle Incised vessels (see Suhm and Jelks 1962). Two notable sherds in the surface collection are a Lindsey Grooved body sherd (Figure 10a), and a Patton Engraved rim sherd (Figures 11 and 12a). The decorative elements on this vessel do not conform to any of the defined varieties of Patton Engraved (see Perttula 2011:Figure 6-66a-d), so it has been dubbed Patton Engraved, var. Walnut Branch. A Patton Engraved, var. unspecified body sherd, with a straight engraved line with tick marks, is also present in the surface collection. There is also a bottle sherd with opposed curvilinear engraved lines (Figure 12b).

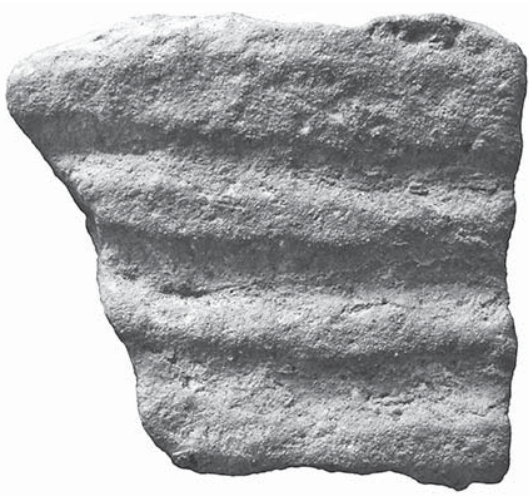

a

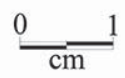

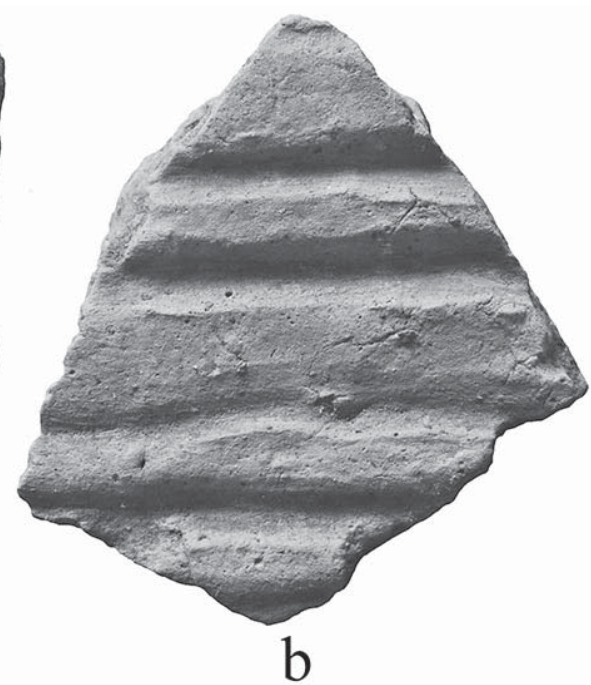

Figure 10. Lindsey Grooved sherds from sites along Walnut Branch: a, surface collection; b, John Ross I site, ST 196, 0-20 cm bs.

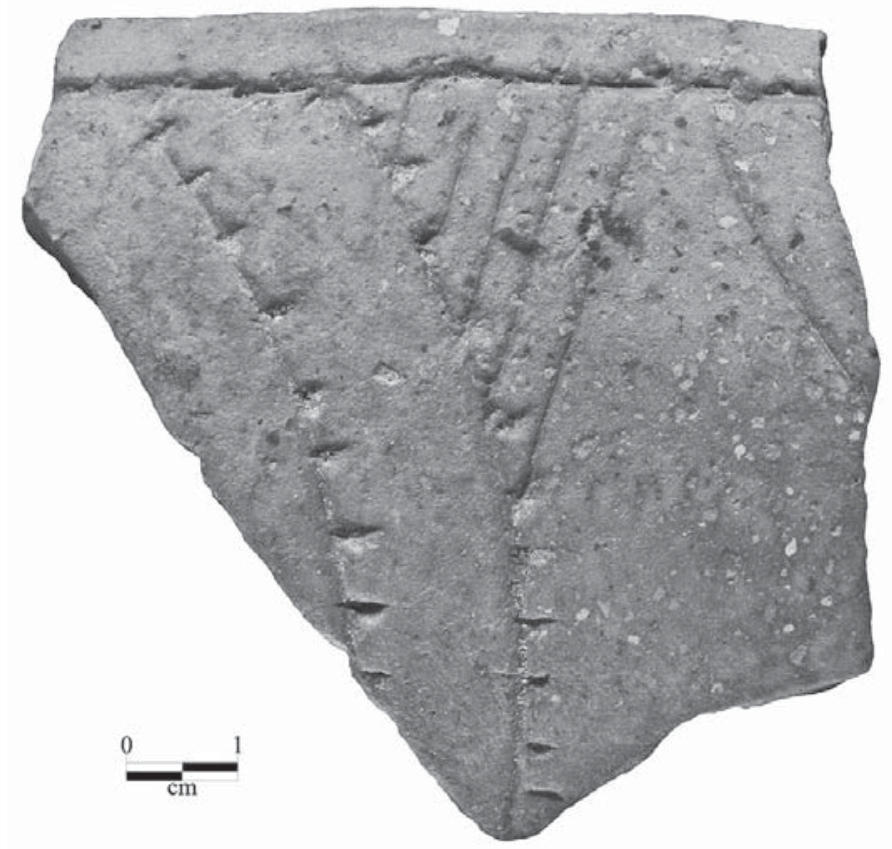

Figure 11. Patton Engraved, var. Walnut Branch rim sherd from the surface collection along Walnut Branch. 


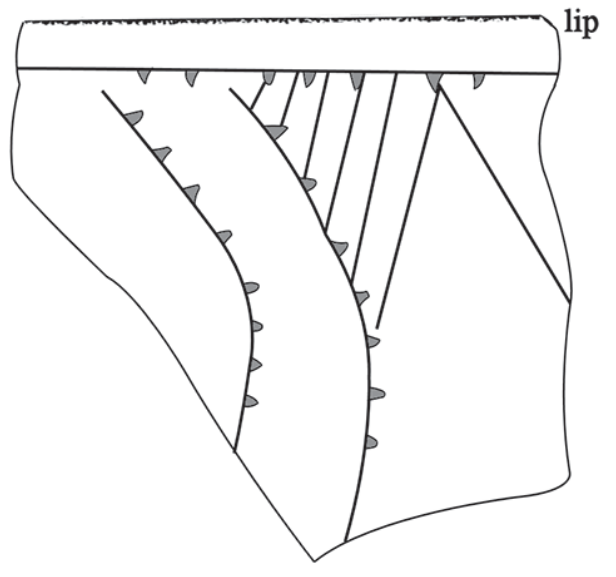

a

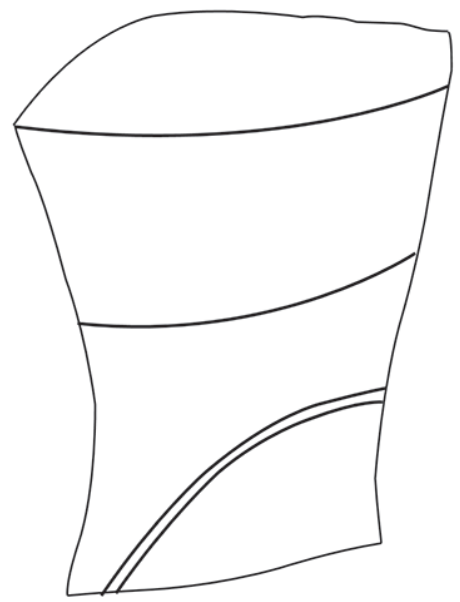

$\mathrm{b}$

Figure 12. Decorative elements on selected fine ware sherds from the 41CE47/41CE485 surface collection.

\section{Walnut Branch (41CE47)}

The principal utility ware sherds at the Walnut Branch site have brushed $(n=103)$ and brushedincised $(n=77)$ decorative elements on the body of jars; none of these sherds are from rims (Table 15 and Figure 13). These body sherds are from Bullard Brushed vessels (see Suhm and Jelks 1962:Plate 11). Utility ware rims have brushed-punctated and incised-punctated decorative elements, as well as a row of tool punctations below the lip. The brushed-punctated rims are also from Bullard Brushed vessels, while the incised-punctated and punctated rims are likely from Maydelle Incised jars (see Suhm and Jelks 1962:Plate 52).

Table 15. Decorative methods and elements in the decorated sherds from the Walnut Branch site.

Decorative method and element

Rim

Body

$\mathrm{N}$

\section{Utility Ware}

\section{Appliqued}

straight appliqued ridge

1

1

\section{Brushed}

opposed brushed marks

overlapping brushed marks

parallel brushed marks

parallel and overlapping brushed marks

Brushed-Appliqued

parallel brushed marks-straight appliqued ridge

$\begin{array}{lll}- & 6 & 6 \\ - & 2 & 2 \\ - & 94 & 94 \\ - & 1 & 1 \\ & & \\ - & 1 & 1 \\ - & 1 & \\ - & 5 & 1 \\ - & 4 & 5 \\ - & 66 & 66 \\ - & 1 & 1\end{array}$

\section{Brushed-Incised}

horizontal incised lines-vertical brushed marks

opposed brushed-incised marks and lines

overlapping brushed-incised marks and lines

parallel brushed-incised marks and lines

parallel brushed-incised marks and lines and curvilinear

incised line 
Table 15. Decorative methods and elements in the decorated sherds from the Walnut Branch site, cont.

Decorative method and eleme
Brushed-Incised-Appliqued
parallel brushed-incised marks

parallel brushed-incised marks and lines and straight

appliqued ridge

Brushed-Punctated

horizontal brushed-tool punctated row below lip

parallel brushed-fingernail punctated row through the

the brushing

parallel brushed-tool punctated row through the brushing

Rim Body

Grooved

parallel grooved

straight grooved

\section{Grooved-Brushed}

straight groove through parallel brushing marks

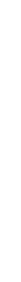

\section{Incised}

horizontal and diagonal incised lines

opposed incised lines

parallel incised lines

closely-spaced parallel incised lines

rectilinear incised lines

straight incised line

$\begin{array}{lll}1 & - & 1 \\ - & 1 & 1 \\ - & 1 & 1\end{array}$

1

Incised-Punctated

horizontal incised line and tool punctated row below

the lip

horizontal-diagonal incised lines and tool punctated row

below the lip

\section{Pinched}

parallel pinched ridges

straight pinched ridge

\begin{tabular}{|c|c|c|}
\hline - & 4 & 4 \\
\hline - & 2 & 2 \\
\hline- & 1 & 1 \\
\hline- & 2 & 2 \\
\hline- & 3 & 3 \\
\hline- & 15 & 15 \\
\hline- & 1 & 1 \\
\hline- & 1 & 1 \\
\hline- & 12 & 12 \\
\hline 2 & - & 2 \\
\hline 1 & - & 1 \\
\hline- & 1 & 1 \\
\hline- & 2 & 2 \\
\hline - & 1 & 1 \\
\hline- & 5 & 5 \\
\hline 3 & - & 3 \\
\hline - & 2 & 2 \\
\hline
\end{tabular}

Punctated

linear tool punctated row

tool punctated row/rows

tool punctated row below the lip

single tool punctation

2

\section{Fine Ware}

\section{Engraved}

circular engraved el. with hatched line

circular engraved el. with tick marks

curvilinear engraved line

curvilinear hatched zones and excised triangle el.

diagonal and curvilinear engraved lines with tick marks

$\begin{array}{lll}- & 1 & 1 \\ - & 1 & 1 \\ - & 3 & 3 \\ - & 1^{* *} & 1 \\ - & 1 & 1\end{array}$


Table 15. Decorative methods and elements in the decorated sherds from the Walnut Branch site, cont.

\begin{tabular}{llll}
\hline Decorative method and element & Rim & Body & N \\
\hline $\begin{array}{l}\text { diagonal engraved line with tick marks and horizontal } \\
\text { engraved line }\end{array}$ & - & 1 & 2 \\
horizontal engraved line & 2 & - & 3 \\
horizontal engraved lines with tick marks & 2 & 1 & 2 \\
opposed engraved lines & - & 2 & 4 \\
parallel engraved lines & - & 4 & 1 \\
parallel engraved lines with tick marks & - & 1 & 1 \\
parallel engraved lines, one with tick marks & - & 1 & 3 \\
rectilinear engraved lines & - & 1 & 1 \\
straight engraved line & - & $5 *$ & 1 \\
straight engraved line with tick marks & - & 3 & 1 \\
straight engraved line with tick marks and cross-hatched & - & 1 & 1 \\
$\quad$ zone & & 1 & \\
$\quad$ straight engraved line and diagonal engraved line with & - & 1 & \\
vertical engraved line & - & & 280 \\
Engraved-Brushed & & & \\
horizontal-diagonal engraved lines-vertical brushed \\
marks
\end{tabular}

*one with white pigment in engraved line

**bottle sherd

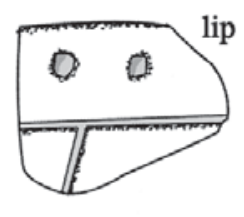

a
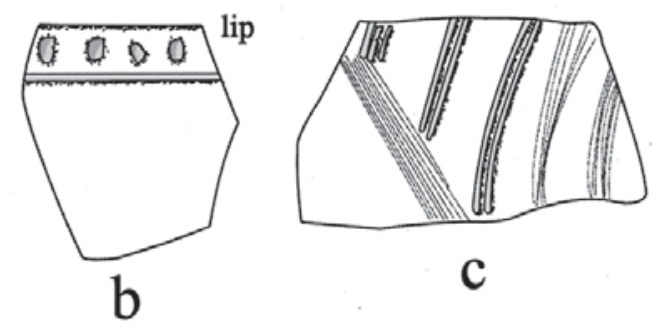

c

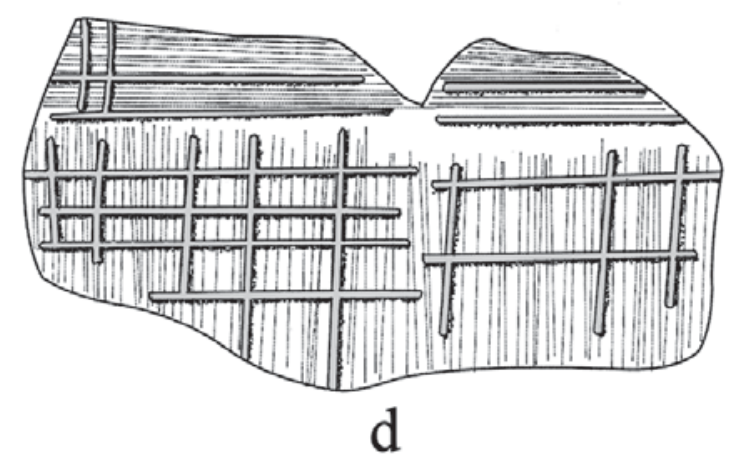

Figure 13. Selected decorative elements on utility ware sherds from the Walnut Branch site. 
Incised sherds at the Walnut Branch site have parallel and straight line elements (see Table 15) as well as horizontal-diagonal and opposed incised lines (see Table 15). They are from the bodies of Maydelle Incised vessels. About 4 percent of the decorated sherds from the site have one or more tool punctated rows, and these sherds are from utility ware jars (see Suhm and Jelks 1962:Plate 79); these punctated jars have not been assigned a type name.

Less common utility ware sherds from the Walnut Branch site are from Lindsey Grooved vessels and Killough Pinched jars (see Table 15; see Suhm and Jelks 1962:Plate 46); together sherds from these types comprise only 3.6 percent of the decorated sherds in the assemblage. Other rare utility wares from the site have appliqued, brushed-appliqued, and brushed-incised-appliqued decorative elements (see Table 15).

The fine wares from the Walnut Branch site have engraved and engraved-brushed decorative elements (see Table 15). About 40 percent of these sherds are from Patton Engraved vessels that have engraved lines with either linear or excised tick marks (Figure 14). These are from Patton Engraved, var. Allen, var. Freeman, and var. Fair vessels (see Perttula 2011:Figure 6-66a, c-d). One sherd with rectilinear engraved lines is from a Mayhew Rectilinear vessel (see Figure 9, and see Jackson et al. 2012). Only one engraved sherd in the Walnut Branch assemblage has a white kaolin clay pigment rubbed in the engraved lines (see Table 15). Finally, one sherd from a globular bowl has horizontaldiagonal engraved lines on the upper part of the vessel, while the body has vertical brushing marks. Brushing of Patton Engraved vessel bodies is considered a common decorative element (Suhm and Jelks 1962:117).

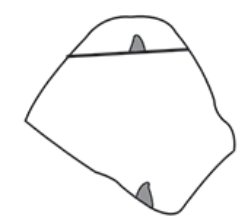

a

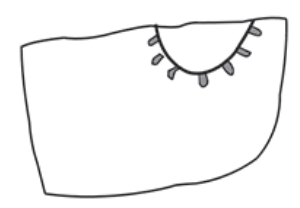

$\mathrm{e}$

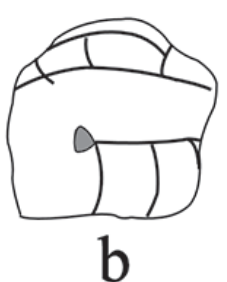

b

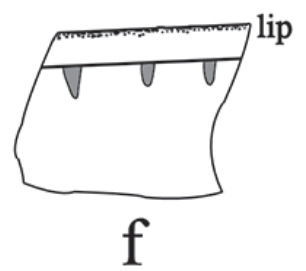

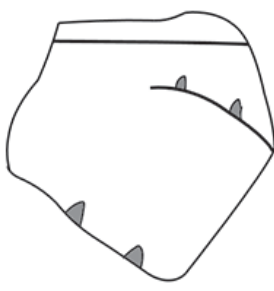

c

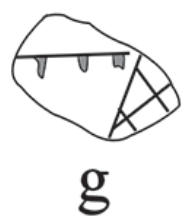

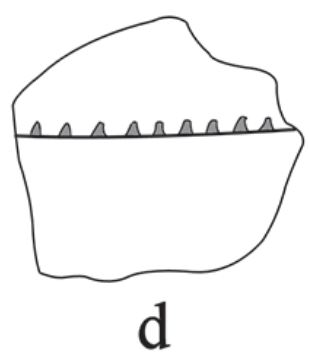

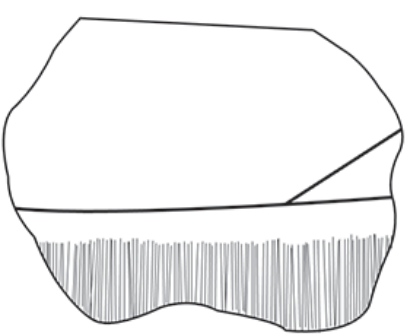

$\mathrm{h}$

Figure 14. Selected decorative elements on fine ware sherds from the Walnut Branch site.

\section{John Ross I (41CE485)}

Brushed and brushed-incised sherds from the body of Bullard Brushed vessels are the principal decorated sherds in the assemblage from the John Ross I site (Table 16), comprising 71 percent of all the decorated sherds from the site. The brushed-incised-punctated and brushed-punctated sherds - another 5.2 percent of the assemblage - are also from Bullard Brushed vessels. 
Table 16. Decorative methods and elements in the decorated sherds from the John Ross I site.

\begin{tabular}{llll}
\hline Decorative method and element & Rim & Body & N \\
\hline
\end{tabular}

\section{Utility Ware}

\section{Brushed}

diagonal brushed marks

opposed brushed marks

overlapping brushed marks

parallel brushed marks

$\begin{array}{lll}- & 1 & 1 \\ - & 2 & 2 \\ - & 1 & 1 \\ - & 39 & 39\end{array}$

Brushed-Incised

opposed brushed-incised marks and lines

parallel brushed-incised marks and lines

parallel brushed and overlying parallel incised lines

$\begin{array}{lll}- & 1 & 1 \\ - & 38 & 38 \\ - & 1 & 1 \\ & & \\ - & 1 & 1\end{array}$

parallel brushed-incised marks and lines and tool

punctated row through the brushing

2

Brushed-Punctated

horizontal brushed marks and adjacent tool punctated row

horizontal brushed marks-tool punctated row through the brushing horizontal brushed marks-tool punctated row below the lip

vertical brushed marks-tool punctated row at side of lip

Grooved

parallel grooves

straight groove

Incised

cross-hatched incised lines

hatched circular incised el.

horizontal-vertical incised lines

horizontal and cross-hatched lines

parallel incised lines

straight incised line

$\begin{array}{lll}- & 1 & 1 \\ 1 & - & 1 \\ 2 & - & 2 \\ 1 & - & 1\end{array}$

Incised-Punctated

curvilinear incised zone filled with linear tool punctations

diagonal opposed incised zone with tool punctations

parallel lines with tool punctated rows between lines

Punctated

tool punctated row

1

\section{Fine Ware}

\section{Engraved}

curvilinear engraved line

hatched triangle element

horizontal engraved line with linear tick marks

opposed engraved lines

straight engraved line

$\begin{array}{lll}- & 1 & 1 \\ - & 1 & 1 \\ - & 1 & 1 \\ - & 1 & 1 \\ - & 7 & 7 \\ - & 1 & 1 \\ & & \\ - & 1 & 1 \\ - & 1 & 1 \\ - & 2 & 2\end{array}$

Totals

5

111 
One brushed-incised sherd from the John Ross I site is from a Spradley Brushed-Incised vessel (see Table 16). This utility ware is found on Historic Caddo Allen phase sites in the Neches-Angelina river basins in East Texas. It consists of parallel brushing elements with overlapping straight incised lines that are opposed or perpendicular to the brushing (Marceaux 2011:140 and Figure 5.2).

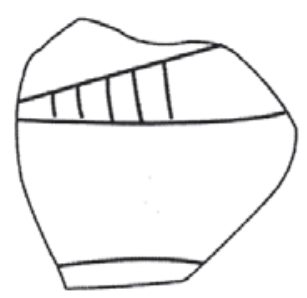

a

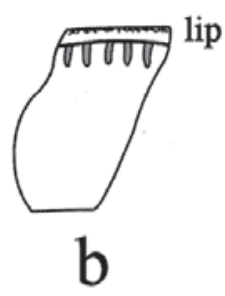

b

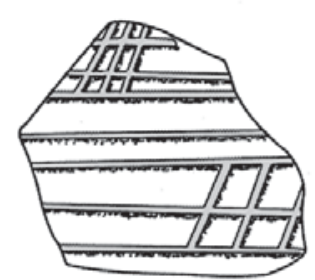

C

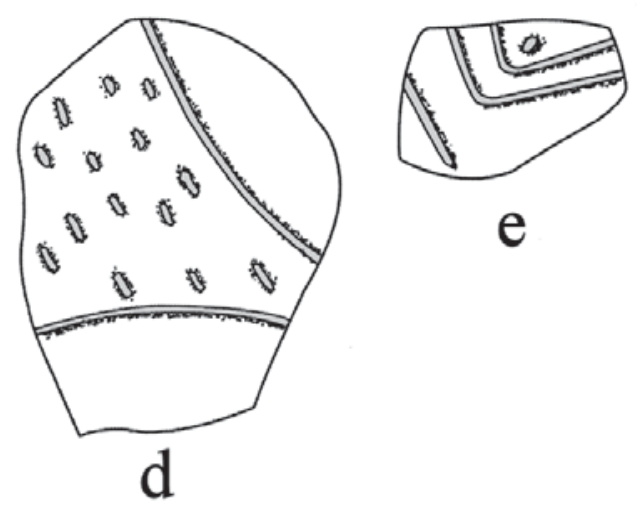

Figure 15. Selected decorative elements on sherds from the John Ross I site.

The sherds with grooved decorative elements at the John Ross I site are from Lindsey Grooved vessels (see Figure 10b), while the incised and incised-punctated sherds are from Maydelle Incised jars (see Table 16). The one tool punctated body sherd comprises only 0.9 percent of the decorated sherds from the site.

The fine wares from the site include sherds from both Poynor Engraved and Patton Engraved vessels. The Poynor Engraved sherd has a hatched triangle element (see Figure 15a), and this element is present on several different defined varieties of the type (see Perttula 2011:Figure 6-64a-d, f-g). The presence of a Poynor Engraved vessel at the site suggests some use of the John Ross site prior to ca. A.D. 1680. The one Patton Engraved sherd in the assemblage is a rim sherd with a single horizontal engraved line with linear tick marks (see Figure 15b). This sherd may be from either a Patton Engraved, var. Allen, var. Freeman, or var. Fair vessel (see Perttula 2011:Figure 6-66a, c-d).

\section{John Ross II (41CE486)}

About 72 percent of the decorated sherds from the John Ross II site are brushed and brushed-incised rim and body sherds from Bullard Brushed vessels (Table 17). Another 18 percent of the sherds have incised and incised-punctated decorative elements, and they are likely from Maydelle Incised vessels. Other utility ware sherds in the assemblage have appliqued ridges $(n=2)$, including a rim sherd that may be from a Cass Appliqued vessel (see Suhm and Jelks 1962:Plate 13), or parallel or straight grooves $(n=3)$; these latter sherds are from Lindsey Grooved jars. 
Table 17. Decorative methods and elements in the decorated sherds from the John Ross II site.

\begin{tabular}{llll}
\hline Decorative method and element & Rim & Body
\end{tabular}

\section{Utility Ware}

\section{Appliqued}

straight appliqued ridge

vertical appliqued ridges below lip

$\begin{array}{lll}- & 1 & 1 \\ 1 & - & 1\end{array}$

\section{Brushed}

horizontal brushed marks

opposed brushed marks

parallel brushed marks

$\begin{array}{lll}1 & - & 1 \\ - & 1 & 1 \\ - & 39 & 39\end{array}$

\section{Brushed-Incised}

opposed brushed-incised marks and lines

(1)

39

parallel brushed-incised marks and lines

$\begin{array}{lll}- & 3 & 3 \\ - & 38 & 38 \\ & & \\ - & 1 & 1 \\ - & 1 & 1 \\ & & \\ - & 1 & \\ & & \\ - & & 1 \\ - & 1 & 12 \\ - & 1 & 5 \\ - & 12 & 1 \\ - & 5 & \end{array}$

\section{Grooved}

parallel grooved

straight grooved

\section{Grooved-Incised}

straight grooved and opposed incised line

\section{Incised}

horizontal-vertical incised lines

opposed incised lines

parallel incised lines

straight incised line

straight, broad, incised line

Incised-Punctated

diagonal incised lines and tool punctation between lines

38

1

2

5

Fine Ware

Engraved

cross-hatched zone, narrow

curvilinear engraved line

curvilinear engraved lines with tick marks

horizontal and diagonal engraved lines with

tick marks; excised punctated row below lip

straight engraved line

straight engraved line with tick marks

Totals

4

3
38
1
1

1

1
1
12
1
1

N


The few fine ware sherds with engraved decorative elements from the John Ross II site include three from Patton Engraved vessels that have tick marks on engraved lines (Figure 16). The sherd with curvilinear engraved lines with tick marks is from either a Patton Engraved, var. Freeman or var. Fair vessel (see Perttula 2011:Figure 6-66c-d). The other two Patton Engraved sherds cannot be identified to a specific variety. The one body sherd with a narrow cross-hatched zone may be from a Hume Engraved vessel (see Perttula 2011:Figure 6-66e, g).
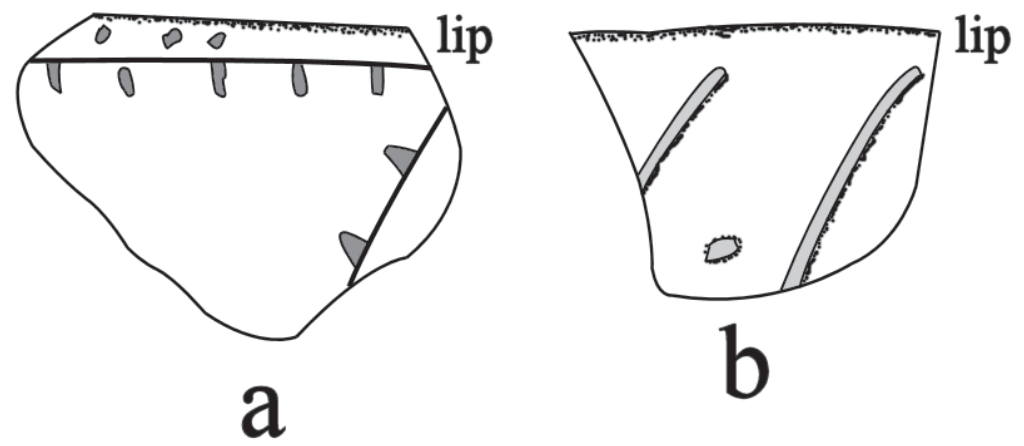

Figure 16. Selected decorative elements on sherds from the John Ross II site.

\section{Temper and Paste Comparisons between the Three sites on Walnut Branch}

Three different temper inclusions are present in the ancestral Caddo ceramic vessel sherds from the sites along Walnut Branch: grog, burned bone, and crushed hematite, either as the sole temper or in combination with one or more of the temper classes (Table 18). These tempers were used in varying proportions by ceramic ware, as well as from one site to another. While many of the ceramic vessel sherds are from vessels with either a clay or silty paste, a significant proportion of the sherds are from vessels with a sandy paste, indicating the use of a natural sandy clay. This data makes clear that more than one source of clay was used by the potters living along Walnut Branch. Clays used for vessel manufacture were probably gathered from nearby alluvial settings, but almost certainly within a short (1-7 km away, at most) distance from the Caddo settlements (e.g., Arnold 2000:343; Arthur 2006:52), so that an inordinate amount of time and energy was not expended by potters in hauling clay back to the sites. Arthur (2006:52) points out that potters would be likely to select lower quality clays for vessel manufacture than high quality clays if the latter were farther away.

Table 18. Temper and paste comparisons between the Walnut Branch (41CE47), John Ross I (41CE485), and John Ross II (41CE486) sites.

\begin{tabular}{|c|c|c|c|c|c|c|c|c|c|}
\hline \multirow{2}{*}{ Temper-paste } & \multicolumn{3}{|c|}{ Plain ware } & \multicolumn{3}{|c|}{ Utility ware } & \multicolumn{3}{|c|}{ Fine ware } \\
\hline & CE47 & CE485 & CE486 & CE47 & CE485 & CE486 & CE47 & CE485 & CE486 \\
\hline B & $1.5^{*}$ & 2.0 & 0.8 & 1.2 & 0.0 & 0.9 & 0.0 & 0.0 & 0.0 \\
\hline $\mathrm{B} / \mathrm{SP}$ & 0.0 & 0.0 & 0.0 & 1.2 & 0.0 & 0.9 & 0.0 & 0.0 & 0.0 \\
\hline B-H & 2.5 & 3.0 & 4.1 & 1.6 & 0.0 & 4.5 & 0.0 & 0.0 & 0.0 \\
\hline B-H/SP & 0.5 & 1.0 & 0.8 & 0.8 & 3.7 & 1.8 & 0.0 & 0.0 & 0.0 \\
\hline G & 21.5 & 25.7 & 25.6 & 27.8 & 16.7 & 22.7 & 37.1 & 25.0 & 50.0 \\
\hline G/SP & 24.0 & 27.7 & 10.0 & 28.2 & 27.8 & 23.6 & 37.1 & 37.5 & 33.3 \\
\hline G-B & 2.0 & 4.0 & 7.4 & 4.9 & 4.6 & 5.5 & 0.0 & 12.5 & 0.0 \\
\hline G-B/SP & 2.5 & 0.0 & 1.7 & 2.8 & 2.8 & 2.7 & 0.0 & 0.0 & 0.0 \\
\hline
\end{tabular}


Table 18. Temper and paste comparisons between the Walnut Branch (41CE47), John Ross I (41CE485), and John Ross II (41CE486) sites, cont.

\begin{tabular}{lccccccccc}
\hline \multirow{2}{*}{ Temper-paste } & \multicolumn{3}{c}{ Plain ware } & \multicolumn{9}{c}{ Utility ware } \\
& CE47 & CE485 & CE486 & CE47 & CE485 & CE486 & CE47 & CE485 & CE486 \\
\hline G-H & & & & & & & & & \\
G-H/SP & 27.5 & 15.8 & 35.5 & 15.5 & 14.8 & 26.4 & 11.4 & 25.0 & 16.7 \\
G-H-B & 15.5 & 13.9 & 9.1 & 12.2 & 21.4 & 8.2 & 14.3 & 0.0 & 0.0 \\
G-H-B/SP & 3.0 & 5.9 & 5.0 & 1.6 & 5.6 & 2.7 & 0.0 & 0.0 & 0.0 \\
H & 0.5 & 0.0 & 0.0 & 1.2 & 2.8 & 0.0 & 0.0 & 0.0 & 0.0 \\
\hline Totals & 0.0 & 1.0 & 0.0 & 0.4 & 0.0 & 0.0 & 0.0 & 0.0 & 0.0 \\
\hline
\end{tabular}

*percentage

$\mathrm{B}=$ bone; $\mathrm{G}=$ grog; $\mathrm{H}=$ hematite; $\mathrm{SP}=$ sandy paste

Regardless of the ware, grog temper is the principal temper employed in the manufacture of plain ware, utility ware, and fine ware vessels at all three sites, followed by the use of hematite, then burned bone (see Table 18). The use of grog temper is highest in the plain wares at the Walnut Branch site, highest in the utility wares at the John Ross I site, and grog temper is present in 100 percent of the fine ware sherds at all three sites. Hematite temper is well represented in the coarser paste plain wares and utility wares (between 33.5-54.5 percent of all these sherds have hematite pieces in the temper), but is present in only 16.7-25.7 percent of the fine ware sherds at the three sites. The use of bone temper is most prevalent in the plain ware sherds at the John Ross II site and the utility ware sherds at the John Ross I site. Of the fine wares, only one of the eight sherds at the John Ross I site have bone temper inclusions; bone temper was not used in the fine ware vessel sherds from the Walnut Branch or John Ross II sites.

The use of sandy paste clays is common in each of the three wares at the three Walnut Branch sites (see Table 18). Among the plain wares, sherds from sandy paste vessels are virtually equally common at the Walnut Branch and John Ross I sites (42.6-43.0 percent). The use of sandy clays in the utility wares at both sites is even higher: 46.5-58.3 percent; only 21.5-34.5 percent of the plain wares at the John Ross II site have a sandy paste. Sandy clays were regularly used for fine ware vessel manufacture at each of the sites, but such clays were most notably used among the fine wares from the Walnut Branch site (51.3 percent).

Table 19 presents summary data (the combined totals for all three wares at each site) on temper use and sandy clay use in the paste of the ceramic vessel sherds at the three Walnut Branch sites. More than 94 percent of the sherds at each of the sites have grog temper, followed by between 39.4-48.5 percent hematite temper use, and then bone temper use from 13.1-19.0 percent by site. The differences between the three sites in overall temper use are not significant.

That is not the case with respect to the use of sandy clays to manufacture ceramic vessels at the Walnut Branch, John Ross I, and John Ross II sites. Between 45.4-50.2 percent of the sherds at the Walnut Branch and John Ross I sites are from vessels manufactured with a naturally occurring sandy clay. Only 29.2 percent of the John Ross II sherds are from vessels made with a sandy clay (see Table 19). This is particularly the case in the plain wares from the site (see Table 18). 
Table 19. Summary of temper use at the three Walnut Branch sites.

\begin{tabular}{llll}
\hline Temper/Paste & $\begin{array}{l}\text { 41CE47 } \\
\text { Walnut Branch }\end{array}$ & $\begin{array}{l}41 \mathrm{CE} 485 \\
\text { John Ross I }\end{array}$ & $\begin{array}{l}\text { 41CE486 } \\
\text { John Ross II }\end{array}$ \\
\hline Grog & $95.6^{*}$ & 94.9 & 94.1 \\
Bone & 13.1 & 17.5 & 19.0 \\
Hematite & 39.4 & 43.8 & 48.5 \\
Sandy Paste & 45.4 & 50.2 & 29.2 \\
\hline Totals & 480 & 217 & 237 \\
\hline
\end{tabular}

*percentages total more than 100 percent because of use of multiple tempers in vessel sherds

\section{Ceramic pipe sherds}

Elbow pipe sherds are present at each of the three sites along Walnut Branch, one sherd apiece at the John Ross I and John Ross II sites, and three sherds at the Walnut Branch site. The first of the elbow pipe sherds from the Walnut Branch site is a plain grog-tempered bowl sherd from ST $114(20-40 \mathrm{~cm} \mathrm{bs})$. The second pipe sherd (ST 116, 0-20 cm bs) is from the base of the bowl and has at least one horizontal row of tool punctations (see Napoleon 1995:Figure 53c-d); the bowl sherd is grog-tempered and $4.8 \mathrm{~mm}$ thick. The last elbow pipe sherd is a plain $2.6 \mathrm{~mm}$ thick bowl rim sherd (Figure 17a) from ST $82(0-20$ $\mathrm{cm}$ bs). the bowl has a sandy paste and grog temper.

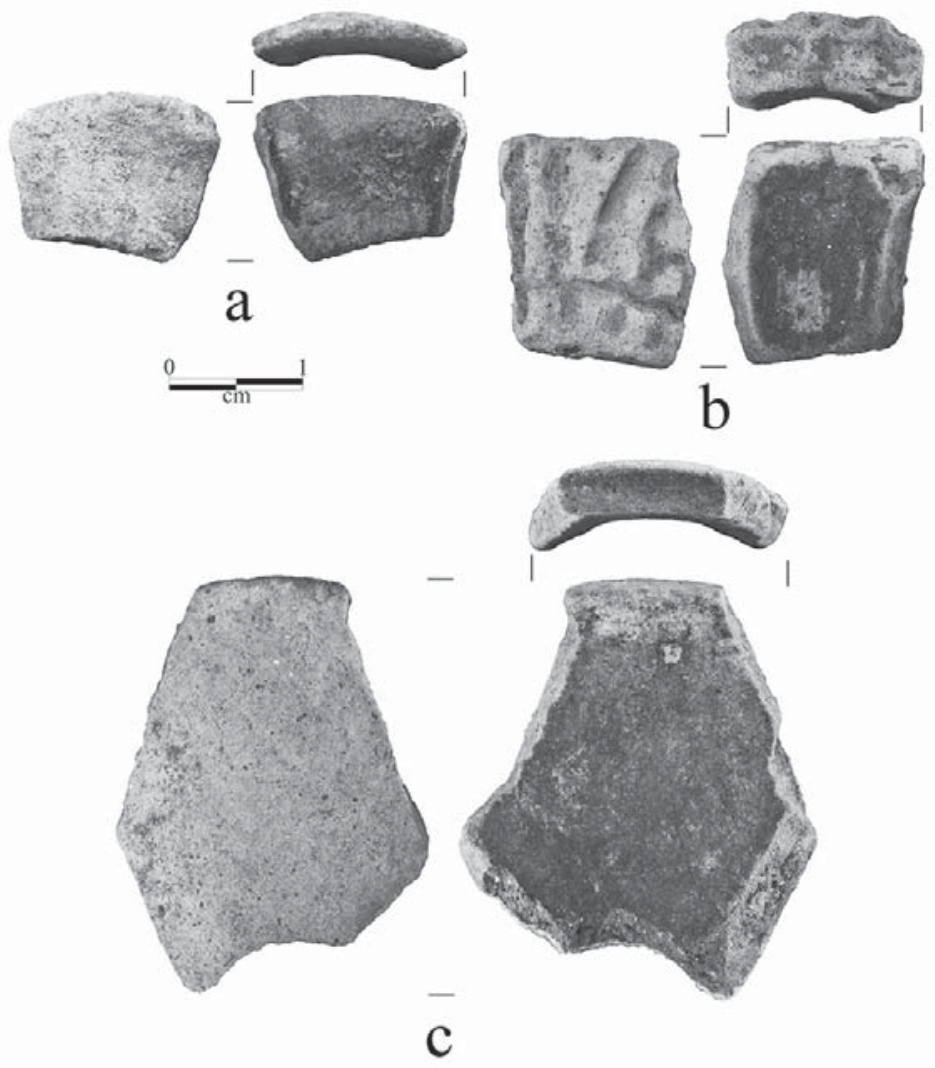

Figure 17. Ceramic elbow pipe sherds: a, Walnut Branch site, ST 82, 0-20 cm bs; b, John Ross II site, ST 185, 0-20 cm bs; c, John Ross I site, ST 199, 20-40 cm bs. 
The elbow pipe sherd from the John Ross I site is a plain bowl rim with a bone-tempered sandy paste (see Figure 17c) from ST 199 (20-40 cm bs). The bowl rim is direct with a flat and interior beveled lip; the bowl is $4.3 \mathrm{~mm}$ thick. The John Ross II site elbow pipe sherd (ST 185, 0-20 cm bs) is from the stem of the pipe, and it has horizontal rows of small punctations divided by a single horizontal incised line (see Figure 17b). Elbow pipes with rows of small punctations are present in other Historic Caddo period Allen phase sites (see Napoleon 1995:Figure 54j; Perttula et al. 2010:Figure 18a). The John Ross II pipe has a sandy paste and is tempered with grog.

\section{Clay coils}

The two clay coil pieces found in the shovel testing at the Walnut Branch site are direct evidence for the on-site manufacture of ceramic vessels made by coiling at the site. The first piece (ST $53,0-20 \mathrm{~cm}$ bs) is $20.0+\mathrm{mm}$ in length and $8.8 \mathrm{~mm}$ in thickness, while the second coil piece (ST 105, 20-40 cm bs) is $8.0 \mathrm{~mm}$ in diameter.

\section{Burned clay pieces}

The few small burned clay pieces ( $n=30$ from the three sites) are likely remnants of clay hearths or earth ovens that were in use during the ancestral Caddo occupations of the sites, or the product of the accidental heating and burning of earth from outdoor fires at the sites. Most of the burned clay pieces are from either the John Ross I site ( $\mathrm{n}=13,43$ percent) or the Walnut Branch site ( $\mathrm{n}=10,33$ percent).

\section{Chipped stone tools}

Only two chipped stone tools were recovered in the shovel testing at the sites along Walnut Branch, both from the Walnut Branch site. The first tool is a fragment of a unifacially chipped triangular arrow point found in ST $116(0-20 \mathrm{~cm}$ bs) (Figure 18a). The triangular arrow point fragment is a Turney point, very similar to those documented at the roughly contemporaneous Henry M site (41NA60) (Perttula et al. 2010:Figure 19f-h) in the Angelina River basin, and it is made from a translucent honey-colored chert of likely Central Texas origin. The point is $15.3 \mathrm{~mm}$ wide at the base and only $2.1 \mathrm{~mm}$ thick. The second tool is a fragment of a bifacial drill from ST $114(20-40 \mathrm{~cm} \mathrm{bs})$ (Figure 18b). the drill is made from a non-local gray chert, and is $8.3 \mathrm{~mm}$ in width. The drill bit is $5.0 \mathrm{~mm}$ wide and $2.2 \mathrm{~mm}$ in thickness.

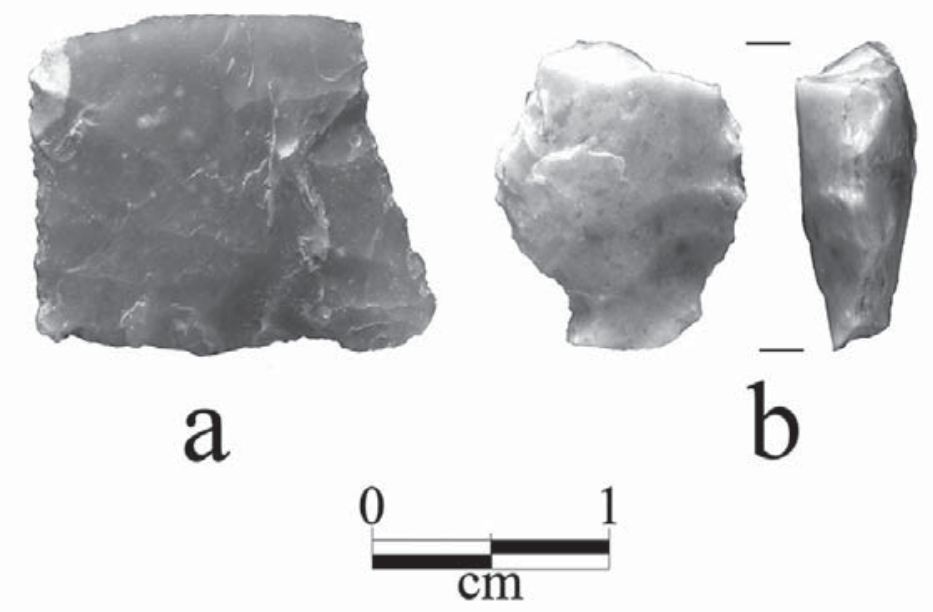

Figure 18. Chipped stone tools from the Walnut Branch site (41CE47): a, triangular arrow point; b, bifacial drill fragment. 


\section{Lithic Debris}

Nineteen pieces of lithic debris were recovered in the shovel testing from the Walnut Branch $(n=9)$ and John Ross II ( $\mathrm{n}=10)$ sites (Table 20); no evidence for the manufacture or maintenance of chipped stone tools were found at the John Ross site I site (41CE485). The majority of the lithic debris are on chert raw materials from non-local sources -67 percent at the Walnut Branch site and 70 percent at the John Ross II site-likely from Central Texas Edwards Plateau sources. Cobbles and pebbles of these cherts can be found in outwash gravels in Neches River gravel sources (see Girard 1995:66; Shafer 1973). The translucent honey-colored chert is also called "beeswax" chert (Miller 2008:27). The only local raw material in the small samples of lithic debris is petrified wood; two pieces of petrified wood lithic debris were collected from the Walnut Branch stream bed during the February 2017 surface collection.

Table 20. Lithic debris from the Walnut Branch (41CE47) and John Ross II (41CE486) sites.

\begin{tabular}{lll}
\hline Raw Material & $\begin{array}{l}\text { Walnut Branch } \\
\text { cortical/non-cortical }\end{array}$ & $\begin{array}{l}\text { John Ross II } \\
\text { cortical/non-cortical }\end{array}$ \\
\hline black chert & $1 /-$ & - \\
light gray chert & - & $-/ 1$ \\
gray chert & $1 / 1$ & $-/ 1$ \\
grayish-black chert & - & $-/ 1$ \\
honey-colored chert & $-/ 1$ & $1 / 1$ \\
dark gray chert & - & $-/ 1$ \\
very dark gray chert & $1 /-$ & - \\
white chert & $-/ 1$ & - \\
yellow chert & - & $1 /-$ \\
petrified wood & $1 / 2$ & $1 / 2$ \\
\hline Totals & $4 / 5$ & $3 / 7$ \\
\hline
\end{tabular}

Between 30-44 percent of the lithic debris from the two sites have cortical remnants (see Table 20), either stream-rolled or roughened. It is probable that cortex-covered pebbles were minimally reduced at the two sites to produce flakes for use in tool manufacture.

\section{Ground Stone tools and Red Ochre}

Shovel testing recovered five ground stone tools and a modified piece of red ochre from the Walnut Branch and John Ross II sites. From the Walnut Branch site, one of these tools is a polished stream-rolled pebble from ST $53(0-20 \mathrm{~cm}$ bs); this pebble was likely used to burnish and polish the surface of ceramic vessels made at the site. There also is a ferruginous sandstone mano fragment $(41+\mathrm{x} 34+\mathrm{mm}$ in length and width) from ST $97(20-40 \mathrm{~cm}$ bs $)$, and a pitted stone from ST $89(10 \mathrm{~cm} \mathrm{bs})$. This ground stone tool is also made from local ferruginous sandstone. It is $70 \times 56 \times 37 \mathrm{~mm}$ in length, width, and thickness, with a $16 \mathrm{~mm}$ diameter pit or depression on one surface of the rock; the depression is $2 \mathrm{~mm}$ in depth. The stone is otherwise unmodified. The piece of red ochre (ST 102, 20-40 cm bs) has a few scratching marks on it, suggesting it was used as a source of pigment.

One of the ground stone tools at the John Ross II site is a ferruginous sandstone pitted stone (ST 163, $17 \mathrm{~cm} \mathrm{bs}$ ). One surface of the cobble has a $5.8 \mathrm{~mm}$ diameter pit or depression; the pit is $8.2 \mathrm{~mm}$ in depth. The unmodified cobble is $92 \times 61 \times 47 \mathrm{~mm}$ in length, width, and thickness. A ferruginous sandstone mano fragment was recovered in ST $190(0-20 \mathrm{~cm}$ bs) at the site. 
The ground stone tools from the three sites also include a greenstone celt polished bit fragment from the surface collection along the Walnut Branch stream bed (Figure 19). The greenstone or siliceous shale raw material was likely obtained from Red River gravels, although its source was the Ouachita Mountains in southeastern Oklahoma.

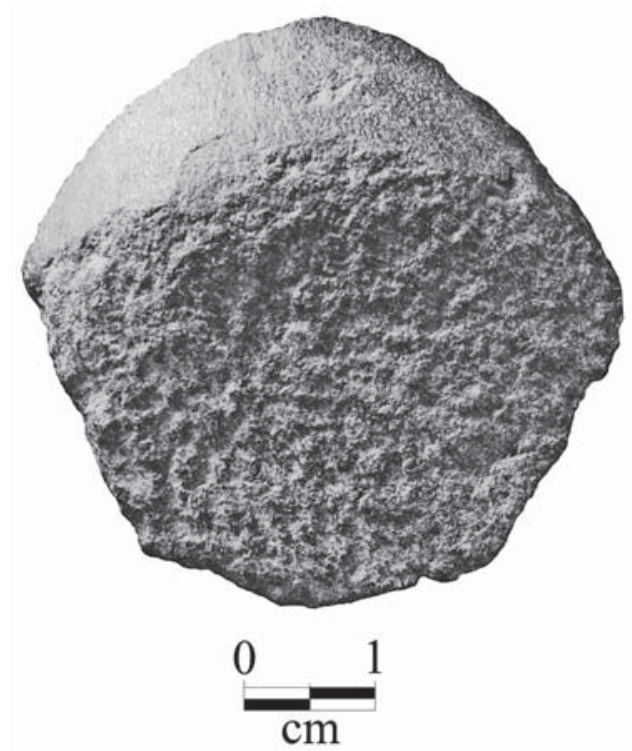

Figure 19. Celt fragment from the Walnut Branch stream bed by the Walnut Branch (41CE47) and John Ross I (41CE485) sites.

\section{Lead Balls}

Two small lead balls of likely early $18^{\text {th }}$ century age and French manufacture (see Jackson et al. 2012:Figures 3-52 and 4-10) were recovered in the shovel testing at two of the site along Walnut Branch. At the Walnut Branch site (41CE47), the lead ball was recovered in ST $78(0-20 \mathrm{~cm}$ bs) near Cluster B. This ball is $9.1 \mathrm{~mm}$ in diameter (36 cal.), dimpled on one side, and it has a cut line at the top of the ball (Figure 20a). The lead ball from the John Ross II site (41CE486) is from ST $163(0-20 \mathrm{~cm}$ bs), northeast of the main artifact clusters A and B. This lead ball is $8.2 \mathrm{~mm}$ in diameter (Figure 20b) or $32 \mathrm{cal}$.

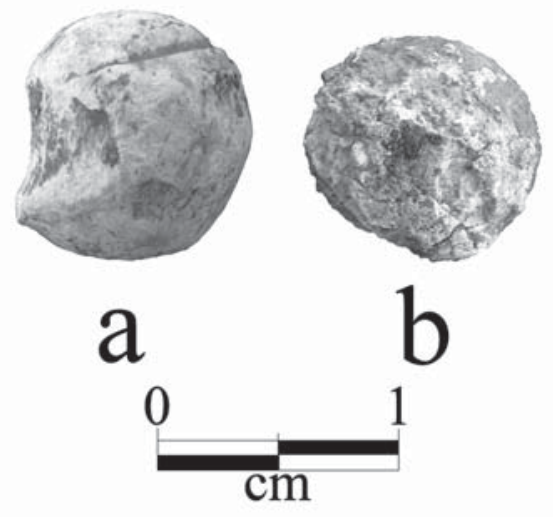

Figure 20. Lead balls from the Walnut Branch (41CE47) and John Ross II (41CE486) sites: a, ST 78, 0-20 cm bs, Walnut Branch site; b, ST 163, 0-20 cm bs, John Ross II site. 


\section{Wood Charcoal and Nutshells}

Pieces of wood charcoal and nutshell are not abundant at any of the three sites on Walnut Branch, indicating the poor preservation of organic remains in the moist fine sandy loam alluvial sediments at the sites. There are 21 pieces of wood charcoal, 71 percent of those pieces being recovered from the Walnut Branch site (41CE47). Of the five pieces of charred nutshell in the collected assemblages, 80 percent are from the John Ross I site (41CE485). One piece of charred nutshell from the Walnut Branch site was submitted for radiocarbon dating (see below).

\section{Animal Bone}

Animal bone is also not well preserved at the three sites on Walnut Branch. Of the 13 pieces recovered in the shovel testing, 61.5 percent are from the John Ross I site (41CE485) archaeological deposits.

\section{Summary and Conclusions}

In 2017, archaeological investigations were conducted at three ancestral Caddo settlements in a floodplain setting along Walnut Branch in the Box's Creek drainage in Cherokee County, Texas: Walnut Branch (41CE47), John Ross I (41CE485), and John Ross II (41CE486); the Walnut Branch site had first been recorded in 1969, but had not been revisited by archaeologists until 2017. The archaeological investigations done in 2017 included a surface collection along the Walnut Branch stream bed parallel to the Walnut Branch and John Ross I sites, as well as intensive shovel testing at all three sites. A total of 139 shovel tests at the three sites contain archaeological materials, mainly from $0-40 \mathrm{~cm}$ bs.

The recovered artifacts - principally ceramic vessel sherds - from the three sites indicate that the sites were occupied primarily in the Historic Caddo Allen phase (dating after ca. A.D. 1680), and are part of a Historic Caddo community, with some use during the Late Caddo period Frankston phase at the Walnut Branch and John Ross I sites. A single radiocarbon date has been obtained on a charred nutshell from the Walnut Branch site. The conventional radiocarbon age of the nutshell is A.D. $1700 \pm$ 36 (D-AMS-024792), and the 2 sigma (95 percent probability) calibrated age range of the sample using IntCal13 (Reimer et al. 2013) is A.D. 1621-1673, dating the nutshell in the occupational deposits to right at the cusp of European contact and at the very end of the Late Caddo period Frankston phase.

In addition to the abundant ceramic vessel sherds, the shovel testing recovered ceramic elbow pipe sherds, chipped stone tools, a single ground stone celt and other ground stone tools, lithic debris, and $18^{\text {th }}$ century lead balls at the Walnut Branch and John Ross II sites. The latter are testimony to Caddo contact with Europeans in the area. Other recovered artifacts include a few pieces of burned clay, wood charcoal, nutshells, and burned and unburned animal bone.

The sites range in size from ca. 1.5 acres (John Ross I), 2.0 acres (John Ross II) to 2.7 acres (Walnut Branch site).The densities of ceramic vessel sherds at the three sites, in combination with other artifact classes and evidence of features encountered in the shovel testing, led to the identification of discrete spatial artifact clusters at each of the three sites: two clusters at the Walnut Branch site, three clusters at the John Ross I site, and two artifact clusters at the John Ross II site. These clusters cover between ca. 900-980 square meters at the three sites, and are likely evidence for 2-3 ancestral Caddo household compounds at each site, along with open areas (informal plazas), and extramural work areas. Remote sensing work is planned in the spring of 2018 around these artifact clusters/household compounds at the three sites along Walnut Branch, along with controlled metal detector work to recover European metal artifacts.

How long were these sites on Walnut Branch occupied by Caddo peoples? Varien's (1999:Table 4.2) ethnographic and archaeological information on the accumulation of utility ware sherds (i.e., what Varien 
[1999] calls cooking pot sherds) in domestic contexts suggests that 4000-8000 grams of cooking pot sherds would be accumulated through breakage and use per year on a residential site occupied by Native American farmers. Based on the size of the defined artifact clusters, the density of sherds per square meter in those artifact clusters ( $>80$ sherds per square meter), and the proportion of utility ware sherds in the assemblages (46-51 percent of the recovered sherds), we estimate that there are approximately 180,000 grams (36,000 sherds, weighing on average 5.0 grams each) of utility ware sherds at the John Ross I site, 184,000 grams (ca. 36,800 sherds) at the John Ross II site, and ca. 196,000 grams (ca. ca. 39,200 sherds) at the Walnut Branch site. These values suggest the utility ware sherds at the three sites would have accumulated in about 22.5-45 years (John Ross I), 23-46 years (John Ross II), and 24.5-49 years (Walnut Branch).

Given that Caddo wood structures would probably only last about 20 years or so before they began to deteriorate and needed to be replaced (see Good 1982:69), then the utility ware accumulation data from the Walnut Branch sites suggests that the artifact clusters were created from ceramic debris deposited either by: (1) one house per cluster or farm compound that may have been used and rebuilt; (2) one or two houses that were in use contemporaneously, each farm compound contributing to the accumulation of ceramic sherd debris; or (3) one or two houses in a farm compound that were occupied at separate times, but close together in time, each contributing at different times to the trash deposits.

The utility metrics of the three Walnut Branch sites indicate there is not a significant technological or stylistic difference in the ceramic assemblages, either in the use of grog or bone temper, in the relative proportion of plain to decorated sherds, brushed to plain sherds, or brushed to other wet paste sherds (Table 21). As such, the three sites constitute a related group of similar ceramic assemblages made by Caddo potters at about the same time that shared a common tradition of ceramic practice.

Table 21. Utility ware metrics at the Walnut Branch sites.

\begin{tabular}{llll}
\hline Metrics & 41CE47 & 41CE485 & 41CE486 \\
\hline percent grog-tempered & 95.6 & 94.9 & 94.1 \\
percent bone-tempered & 13.1 & 17.5 & 19.0 \\
P/DR & 0.71 & 0.87 & 1.06 \\
B/PL & 0.94 & 0.88 & 0.72 \\
B/OWP & 1.34 & 1.37 & 1.26 \\
\hline
\end{tabular}

$\mathrm{P} / \mathrm{DR}=$ plain to decorated sherd ratio; $\mathrm{B} / \mathrm{Pl}=$ brushed/plain sherd ratio; $\mathrm{B} / \mathrm{OWP}=$ brushed/other wet paste sherd ratio

The Walnut Branch sites appear to be related to the Allen phase components previously recognized as belonging to the Neche cluster (Perttula 2017a). The Neche cluster of ceramic vessel sherd assemblages includes several Allen phase Historic Caddo sites on Bowles Creek and the Neches River (41CE291) as well as one Late Frankston phase (ca. A.D. 1560-1680) investigated component of the George C. Davis site (41CE19) (Fields and Thurmond 1980) on the northern part of the terrace east of the Neches River, and a Middle Caddo component at 41CE289 (Figure 21). The Allen phase components in Groups I and II have high proportions of brushed sherds and ratios of brushed to other wet paste sherds (Table 22). These assemblages are almost exclusively comprised of grog-tempered vessels, but differences between the sites in the proportion of bone-tempered vessels (either as the sole temper or in combination with grog) suggest that two contemporaneous groups of Allen phase sites are present in the Neche cluster. These two groups (I and II) also are notably different in brushed to plain sherd ratios (Table 22). 


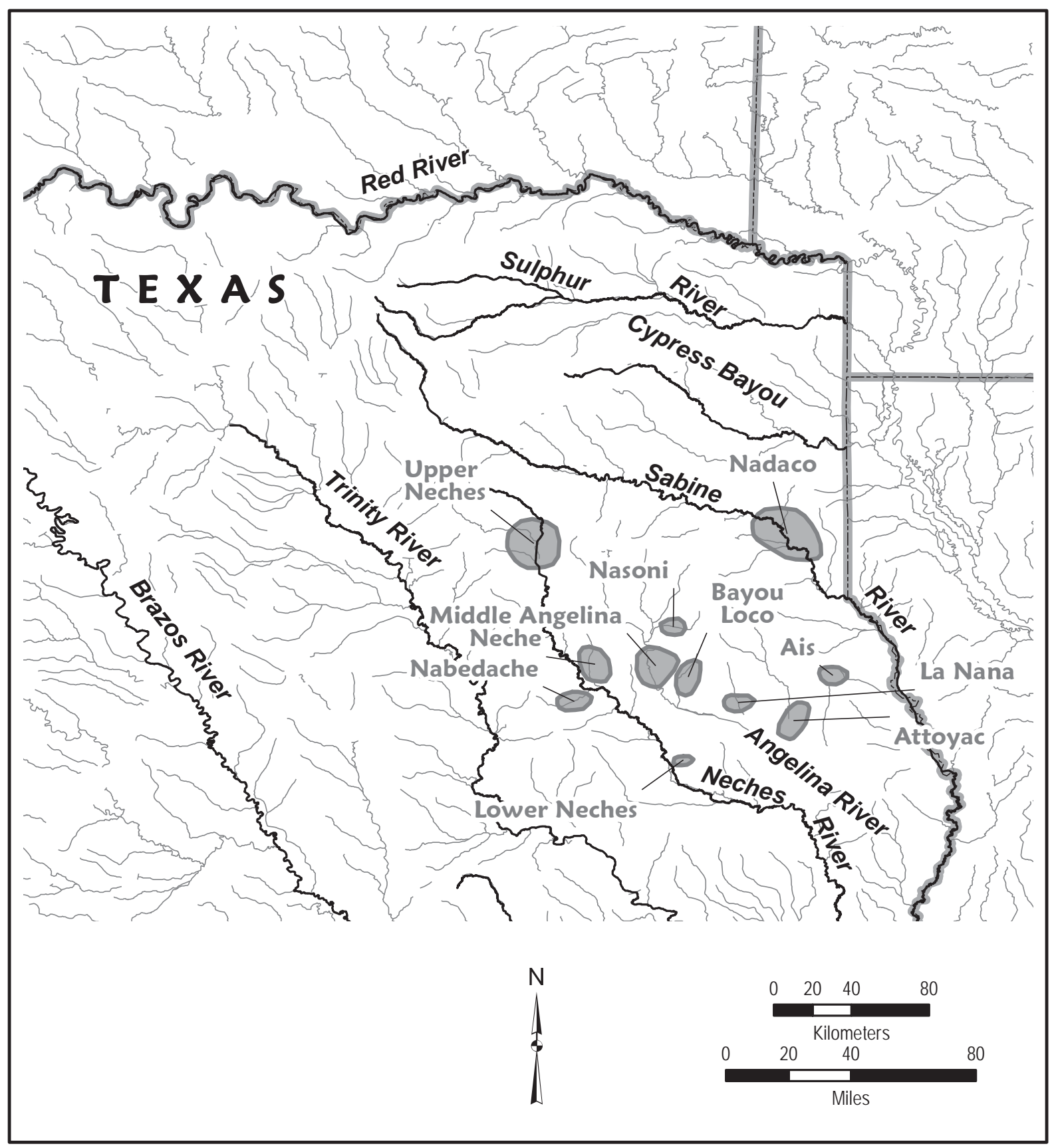

Figure 21. Defined Historic Caddo ceramic clusters in East Texas, including the Neche cluster. 
Table 22. Ceramic sherd assemblage comparisons of Neche cluster sites on Bowles Creek, Box's Creek, and the Neches River.

\begin{tabular}{|c|c|c|c|c|c|}
\hline Site & $\%$ Grog & $\%$ Bone & $\mathrm{P} / \mathrm{DR}$ & $\mathrm{B} / \mathrm{Pl}$ & $\mathrm{B} / \mathrm{OWP} * *$ \\
\hline \multicolumn{6}{|c|}{ Allen phase (ca. post-A.D. 1680} \\
\hline \multicolumn{6}{|c|}{ Group I } \\
\hline$\overline{41 C E 293}$ & 98.1 & 5.6 & 0.12 & 7.50 & 5.70 \\
\hline 41CE43 & 96.1 & 3.9 & 0.17 & 4.91 & 6.08 \\
\hline 41CE477 & 98.5 & 1.5 & 0.37 & 2.25 & 7.02 \\
\hline 41CE474 & 97.1 & 2.9 & 0.30 & 3.08 & 9.25 \\
\hline 41CE291 & 97.4 & 2.6 & 0.30 & 1.94 & 1.84 \\
\hline \multicolumn{6}{|l|}{ Group II } \\
\hline $41 \mathrm{CE} 48$ & 84.2 & 27.7 & 0.31 & 2.43 & 5.48 \\
\hline 41CE475 & 89.5 & 10.5 & 0.40 & 2.07 & 7.60 \\
\hline 41CE20 & 85.7 & 14.3 & 0.40 & 2.07 & 5.0 \\
\hline $41 \mathrm{CE} 476$ & 91.2 & 9.2 & 0.45 & 1.77 & 7.0 \\
\hline \multicolumn{6}{|l|}{ Group III } \\
\hline $41 \mathrm{CE} 47$ & 95.6 & 13.1 & 0.71 & 0.94 & 1.34 \\
\hline 41CE485 & 94.9 & 17.5 & 0.87 & 0.88 & 1.37 \\
\hline 41CE486 & 94.1 & 19.0 & 1.06 & 0.72 & 1.26 \\
\hline \multicolumn{6}{|c|}{ Late Frankston phase (ca. A.D. 1560-1680) } \\
\hline \multicolumn{6}{|c|}{ Group III } \\
\hline $\begin{array}{l}\text { 41CE19, } \\
\text { Northern } \\
\text { part of site }\end{array}$ & N/A & N/A & 0.82 & 0.78 & 1.90 \\
\hline \multicolumn{6}{|c|}{ Possible Middle Caddo occupation, ca. A.D. 1300-1400 } \\
\hline $41 \mathrm{CE} 289$ & 82.1 & 17.9 & 1.38 & 0.49 & 2.38 \\
\hline 41CE481 & 77.4 & 22.6 & 2.00 & 0.26 & 1.31 \\
\hline
\end{tabular}

Sources: Perttula 2017b; Perttula and Stingley 2017; Perttula et al. 2017

$\mathrm{P} / \mathrm{DR}=$ plain to decorated sherd ratio; $\mathrm{B} / \mathrm{Pl}=$ brushed/plain sherd ratio; $\mathrm{B} / \mathrm{OWP}=$ brushed/other wet paste sherd ratio

The Walnut Branch sites are included in Group III of the Allen phase components in the Neche cluster (see Table 22), while acknowledging the likelihood that at least one or more of the sites were apparently occupied during the latter years of the Late Caddo Frankston phase. The proportion of grog temper use in these sites is comparable to the Group I components, while the use of bone temper is much like the Group II sites. Where the Group III components on Walnut Branch differ from the Group I and II Allen phase Neche cluster sites is in the much higher proportion of plain sherds to decorated sherds in the Walnut Branch sites, along with lower ratios of brushed to plain sherds and brushed to other wet paste sherds. As such, the Walnut Branch sites ceramic vessel sherd data are considered to represent another community of Historic Allen phase Caddo peoples in the middle reaches of the Neches River basin, but one related to the Group I and II communities by the manufacture and use of Patton Engraved, Bullard Brushed, Maydelle Incised, Lindsey Grooved, and Killough Pinched vessels. 


\section{Acknowledgments}

Lance Trask, Sandra Hannum, Tom Middlebrook, and Kevin Stingley prepared the figures in this article. Thanks also to Tom Middlebrook for input about the lead balls recovered at the Walnut Branch and Ross II sites during the shovel testing investigations.

\section{References Cited}

Arnold, D. E.

2000 Does the Standardization of Ceramic Pastes Really Mean Specialization? Journal of Archaeological Method and Theory 7:333-375.

Arthur, J. W.

2006 Living with Pottery: Ethnoarchaeology among the Gamo of Southwest Ethiopia. The University of Utah Press, Salt Lake City.

Fields, R. and J. P. Thurmond

1980 The George C. Davis Site, Cherokee County, Texas: Spring 1980 Archeological Investigations. Reports of Investigations No. 8. Prewitt and Associates, Inc., Austin.

Fitts, M. E.

2017 Fit for War: Sustenance and Order in the Mid-Eighteenth-Century Catawba Nation. University of Florida Press, Gainesville.

Girard, J. S.

1995 The Chipped Stone Collection: Technological, Functional, and Typological Analyses. In the Deshazo Site, Nacogdoches County, Texas, Volume 2: Artifacts of Native Manufacture, edited by D. A. Story, pp. 33-156. Studies in Archeology 21. Texas Archeological Research Laboratory, The University of Texas at Austin.

Good, C. E.

1982 Analysis of Structures, Burials, and other Cultural Features. In The Deshazo Site, Nacogdoches County, Texas, Volume I: The Site, Its Setting, Investigation, Cultural Features, Artifacts of Non-Native Manufacture, and Subsistence Remains, edited by D. A. Story, pp. 51-112. Texas Antiquities Permit Series No. 7. Texas Antiquities Committee, Austin.

Jackson, M. K., T. Middlebrook, G. Avery, H. Shafer, and B. Meissner

2012 Trade and Cultural Interaction Along El Camino Real de los Tejas During the Spanish Colonial and Republic Periods in Nacogdoches County, Texas. 2 Vols. Nine Flags Museum, Nacogdoches, Texas.

Marceaux, P. S.

2011 The Archaeology and Ethnohistory of the Hasinai Caddo: Material Culture and the Course of European Contact. Ph.D. dissertation, Department of Anthropology, The University of Texas at Austin.

Miller, K. A.

2008 A Study of Prehistoric Biface Caches from Texas. La Tierra 34(1\&2):1-88.

Mowery, I. C.

1959 Soil Survey, Cherokee County, Texas. United States Department of Agriculture, Soil Conservation Service, in cooperation with Texas Agricultural Experiment Station, Washington, D.C.

Napoleon, P. N.

1995 Analysis of Native-made Ceramic Pipes. In the Deshazo Site, Nacogdoches County, Texas, Volume 2: Artifacts of Native Manufacture, edited by D. A. Story, pp. 157-171. Studies in Archeology 21. Texas Archeological Research Laboratory, The University of Texas at Austin. 
Perttula, T. K.

2011 The Ceramic Artifacts from the Lang Pasture Site (41AN38) and the Place of the Site within an Upper Neches River Basin Caddo Ceramic Tradition. In Archeological Investigations at the Lang Pasture Site (41AN38) in the Upper Neches River Basin of East Texas, assembled and edited by T. K. Perttula, D. B. Kelley, and R. A. Ricklis, pp. 145-320. Archeological Studies Program Report No. 129, Texas Department of Transportation, Environmental Affairs Division, Austin.

2017a Utility Ware Ceramic Metrics and Hasinai Caddo Archaeology in East Texas. Journal of Northeast Texas Archaeology 70:61-68.

2017b Analysis of Ancestral Caddo Ceramic Assemblages from the Gas Line Site (41CE63) and 41CE289, Neches River Basin, Cherokee County, Texas. Journal of Northeast Texas Archaeology 72:43-49.

Perttula, T. K. and K. Stingley

2017 Test Excavations and Additional Surface Collections at the Peach Orchard Site (41CE477) on Bowles Creek in Cherokee County, Texas. Journal of Northeast Texas Archaeology 73:81-93.

Perttula, T. K., L. L. Bush, L. Schniebs, T. Middlebrook, and P. S. Marceaux

2010 An Early Historic Caddo Farmstead at the Henry M. Site (41NA60) in Nacogdoches County, Texas. Stephen F. Austin State University Press, Nacogdoches, Texas.

Perttula, T. K., K. Stingley, and M. Walters

2017 Archaeological Investigations at the Bowles Creek Site (41CE475), Cherokee County, Texas, in Early 2017. Journal of Northeast Texas Archaeology 74:85-95.

Reimer, P. J., E. Bard, A. Bayliss, J. W. Beck, P. G. Blackwell, C. Bronk Ramsey, C. E. Buck, H. Cheng, R. L.

Edwards, M. Friedrich, P. M. Grootes, T. P. Guilderson, H. Haflidason, I. Hajdas, C. Hatte, T. J. Heaton, D. L. Hoffmann, A. G. Hogg, K. A. Hughen, K. F. Kaiser, B. Kromer, S. W. Manning, M. Niu, R. W. Reimer, D. A. Richards, E. M. Scott, J. R. Southon, R. A. Staff, C. S. M. Turney, and J. van der Plicht

2013 IntCal13 and Marine13 Radiocarbon Age Calibration Curves 09-50,000 Years Cal BP. Radiocarbon 55(4):1869-1887.

Shafer, H. J.

1973 Lithic Technology at the George C. Davis Site, Cherokee County, Texas. Ph.D. dissertation, Department of Anthropology, The University of Texas at Austin.

Suhm, D. A. and E. B. Jelks (editors)

1962 Handbook of Texas Archeology: Type Descriptions. Special Publication No. 1, Texas Archeological Society, and Bulletin No. 4, Texas Memorial Museum, Austin.

Varien, M. D.

1999 Sedentism and Mobility in a Social Landscape: Mesa Verde and Beyond. University of Arizona Press, Tucson. 